\title{
Challenges in perishable food supply chains for sustainability management: A developing economy perspective
}

\section{Kumar, A}

http://hdl.handle.net/10026.1/17767

\subsection{2/bse.2470 \\ Business Strategy and the Environment \\ Wiley}

All content in PEARL is protected by copyright law. Author manuscripts are made available in accordance with publisher policies. Please cite only the published version using the details provided on the item record or document. In the absence of an open licence (e.g. Creative Commons), permissions for further reuse of content should be sought from the publisher or author. 


\section{Challenges in Perishable Food Supply Chains for Sustainability Management: A developing economy perspective}

Abstract: Perishable food supply chains (PFSCs) are characterized with rising food quality and safety concerns, alarming food wastages and losses, and poor economic sustainability. Owing to the perishable nature of products and limited shelf life, management of sustainability in PFSCs is critical. Many studies on sustainability in PFSCs have considered developed countries; however, developing countries, have not gathered the required research attention in this domain. In this paper, a decision-theory based framework is adopted, where a prescriptive decision analysis methodology is used to generate preferences among the challenges to sustainability in PFSC. An integrated Interpretive Structural Modelling-Analytic Network Process (ISM-ANP) decision framework is formulated to identify and model key challenges to sustainability in PFSCs, keeping a developing economy like India under consideration. The contextual relationships amongst the extracted challenges are analysed using Interpretive Structural Modelling (ISM) methodology. The relationships identified from ISM are used as inputs in the Analytic Network Process (ANP) methodology, to generate the priority weights of the challenges. The findings of the integrated methodology show "Lack of horizontal integration of farmers", "poor pre-harvest management", "lack of government regulation and support" to be the most critical challenges for sustainability in PFSCs. The results show that organizations must work on aggregation of farm produce and integration of farmers with the market. Development of infrastructures and cold chain facilities at the farm level are necessary to mitigate these challenges to reduce wastages in PFSC. The study facilitates managers and planners to understand and enable sustainable practices in PFSCs.

Keywords: Perishable Food Supply Chain (PFSC); Sustainability Management; ISM - ANP; Environmental Performance; Challenges; Developing economy.

\section{Introduction}

Sustainable development is a global necessity for industries across different fields and domains. Organizations across the globe are trying hard to minimize their environmental footprints but find it difficult to achieve without striking a balance between the environment, society and economy. The challenge of sustainability is even greater in food supply chains (FSCs). To be able to sustainably feed a global population of 10 billion by 2050 is the greatest challenge that humanity will face. 
In the current scenario, almost one-third of the total food production is wasted/lost globally (Food and Agriculture Organization of the United Nations, 2019). The amount of food wasted globally would require approximately $230 \mathrm{~km}^{3}$ of water and 300 million barrels of oil for its production (Gardas et al., 2018). Perishable Food Products (PFPs), like fruits and vegetables, constitute about $70 \%$ of the total wasted food (Gardas et al., 2018). Wastage of PFPs incur the loss of an enormous amount of natural resources; as a result, large amounts of resources that go into the production, transportation, and marketing of these food products gets wasted (Sgarbossa and Russo, 2017). Thus, identification of key challenges to achieve sustainability of PFSC is the focal point of this research.

Various product features like the environmental sensitivity and perishability of products , uncertainty in harvest and production yield, and fluctuating demand add to unsustainability in perishable food supply chains (PFSCs) (Van Der Vorst and Beulens, 2002). Wastage and spoilage, supply chain (SC) inefficiencies, environmental footprints of operations, safety issues due to the organic nature of the product, etc., are various problems in the sustainable management of PFSCs. PFSC includes various actors like IInd tier suppliers of seeds, fertilizers, farm machinery suppliers; farmers; cold chain service providers; organizations; wholesale market; local retailers; end customers; and waste collection services, as shown in Fig 1. All these actors engage in various activities like farming, harvesting, packing and processing, logistics, wholesaling, and retailing. A system perspective, thus, is required to understand the complexities and challenges to sustainability in the PFSCs.

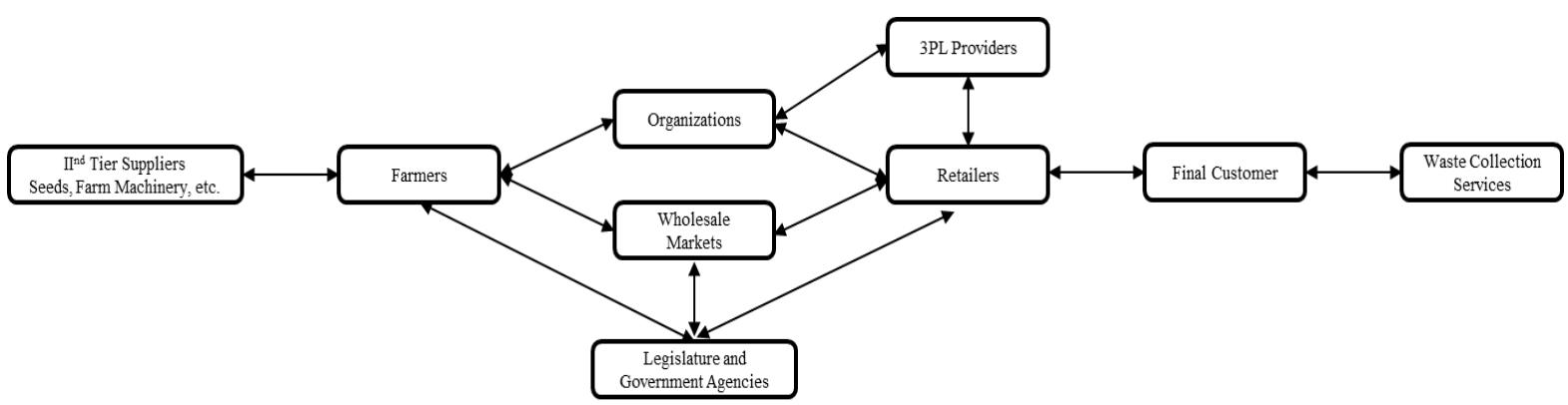

Fig. 1. A PFSC theoretical diagram

The challenge of food waste reduction in developing economies has not received due attention (Joshi and Visvanathan, 2019). Considering the fact that by the year 2050 developing countries will account for $90 \%$ of the world's population, managing these challenges from the perspective of developing nations is crucial. The pattern of food wastage in developing countries is somewhat different than developed countries. According to a report by the High 
Level Panel of Experts on food security and nutrition (HLPE), Food and Agriculture Organization of United Nations (Pinstrup-Andersen et al., 2014), the food loss and wastage in developed countries is more at the consumer's end; with almost $40 \%$ of the food wasted or lost only at the consumer's end in North America. The wastage of PFPs in low-income and developing countries, occurs more at the early stage of food value chains, at the farms, and during storage and transportation, less at the customer end (Pinstrup-Andersen et al., 2014). The difference in the pattern may be due to infrastructural deficiency, technical, financial, and managerial constraints, and structural inefficiencies in the food supply chains. Further, organizations have been slow in the uptake of sustainable practices in developing countries. In China alone, 370 million tons of fruits and vegetables deteriorate due to poor logistics performance and unsustainable supply chain design (Shabani et al., 2012). A huge $40 \%$ of the total agricultural produce is wasted in India, which demonstrates the enormity of the problem at hand (Gardas et al., 2018; Shabani et al., 2012). Sustainability of the PFSC poses a major challenge in India, home to $17 \%$ of global population, with almost half of its population relying on agriculture for employment. With a severely stressed agri-economy employing half of its population and producing huge amounts of waste, the PFSC underperforms on all three dimensions of the Triple Bottom Line (TBL).

Opportunity lies in the domain of PFPs in India, from the point of view of TBL sustainability (Team Inc42, 2017). There is a wide range of opinions on how to achieve this and which dimension of TBL should be prioritized (Davis-Sramek et al., 2018). The challenges identified in this research are based on the grounds of TBL theory. The present research presents analyses of various challenges for the TBL view of sustainability in PFSC and tries to explore key research questions as follows:

Q1. What are the key challenges in the PFSC to the TBL of sustainability in developing countries?

Q2. What are the contextual relationships among the challenges to sustainbaility in the PFSC? Q3. How are these challenges priortised for sustainability in the PFSC?

The present problem is an operations research based decision problem, as the objective of the whole exercise is to help decision makers to prioritize the challenges of sustainability that they face in PFSC. Thus, a Decision Theory (DT) based approach is followed. Scholars identify three basic paradigms of decision making: normative, descriptive, and prescriptive. The normative approach identifies how a decision "ought to be" made in a rational ideal world. The 
descriptive approach identifies how the real world behaves, and is more empirical in nature. The prescriptive approach tries to explain the, "what should be", of decision making. It is premised on the concept of "bounded rationality", introduced by Simon (1960). French et al. 2009 explain how the principles of normative and descriptive theory can be used together to arrive at "prescriptive decision analysis". An integrated interpretive structural modellinganalytic network process (ISM-ANP) methodology was found appropriate for this kind of problem (Bhadani et al., 2016). The Analytic Network Process (ANP) is a generalised form of the Analytic Hierarchy Process (AHP), which is an original and distinct prescriptive decision making method (Tang et al., 2018). The ANP is an effective decision support tool in situations of complex and vibrant decision environments (Malviya et al., 2018). It is predicated on four principles of decision making: decomposition, comparative judgement, priority synthesis, and a process based on social consensus. The methodology essentially integrates the rich descriptive knowledge base of the experts about the criterion, stakeholders, and alternatives, in a normative framework to generate priorities. On the basis of prescriptive decision theory, the methodological route for the present problem consists of:

- Clear specification of alternatives and criteria, which represent the set of challenges to sustainability in PFSC, using expert interviews and literature.

- A hierarchical decomposition of the set of challenges in the problem to generate cognitive understanding of their contextual interrelations.

- Pairwise comparisons based on "importance" criterion, generating alternative weights and priorities.

Such an integrated approach can help managers and policy makers to not only make strategy to mitigate these challenges, but also develop strategies across different planning horizons based on the results of the integrated methodology (Bhadani et al., 2016). The next section presents a literature review of the PFSC, discusses the gaps found in the literature and develops a theoretical framework of the problem.

\section{Literature review}

In the following section the literature on PFSCs is discussed and the key issues and challenges identified in the relevant literature are discussed. 


\subsection{Challenges to Sustainability in PFSCs}

Integrating perishability is an important factor in the design of FSCs (Jonkman et al., 2019). The product quality in PFSCs is significantly contingent on harvesting conditions, weather conditions, storage, and transportation. Thus, SC design plays a crucial role in managing PFSCs (Balaji and Arshinder, 2016). There have been several studies focusing on PFSCs (Ali et al., 2017; Blackburn and Scudder, 2009; Rijpkema et al., 2014). Amorim et al. (2013), reviewing the literature that included the aspect of perishability in planning and distribution problems, identified that the perishability component in the food sector needs to be addressed comprehensively. Shukla and Jharkharia (2013), reviewing the literature related to agri-fresh products supply chains, reported customer satisfaction, maximizing revenue, and Post-Harvest Loss (PHL) reduction as the critical challenges in PFSCs.

A few studies related to sustainability in food supply chains have been conducted, which majorly includes food supply chain (Chauhan et al., 2019; Sgarbossa and Russo, 2017; Sharma et al., 2019), agri-retail SC (Naik and Suresh, 2018), cold chains (Singh and Shabani, 2016), and agri-supply chains (Chauhan et al., 2018). Recent studies propose a shift from the traditional financial perspective to TBL focussed approach (Chkanikova, 2016), however, decisions regarding risks and challenges in this new approach are still less studied. Many studies have highlighted various risks, challenges and barriers in PFSCs. Prakash et al. (2017) identify risks in PFSCs in the four categories of environment, supply, demand, and process risk. Raut et al. (2018) found a lack of connections between institution, industry, and government as the most crucial driver of PHL in India. Gokarn and Kuthambalayan (2017) identified food characteristics like perishability, quality variations, bulkiness, seasonality, policy regulations and infrastructure as the important challenges inhibiting reduction of wastage in FSCs.

Lack of considering food characteristics and quality in SC design and planning is a substantial challenge to sustainability of PSFCs (Deng et al., 2019). Siddh et al. (2018) explored the relationship between PFSC quality and sustainability based organization performance. Product wastage and spoilage due to loss of quality and lack of standardized quality control are important factors in PFSCs (Balaji and Arshinder, 2016; Gligor et al., 2018; Osvald and Stirn, 2008; Rijpkema et al., 2014). Strict temperature control and temperature management is essential to minimize food wastage of PFPs (Ali et al., 2018). Derens-Bertheau et al. (2015) tracked the time-temperature data in a cold chain and identified customer end as a significant source of temperature abuse. 
The lack of cold chain infrastructure is a massive challenge in the management of PFSCs in India (Joshi et al., 2009; Negi and Anand, 2016, 2015). Lack of cold storage, ripening chambers, and other supporting infrastructure at the farm level are significant causes of PHL in fresh produce and agri-supply chains (Gardas et al., 2018; Murthy et al., 2009). Singh and Shabani (2016) identified key success factors, as well as hurdles for sustainable cold chain management. Infrastructure related issues, like road, power and market availability, have been especially highlighted in articles that focussed on developing countries like Vietnam, India, etc. (Gligor et al., 2018; Gokarn and Kuthambalayan, 2017; Naik and Suresh, 2018; Srivastava et al., 2015).

Sharing information and traceability can improve the efficiency of PFSCs by reducing demand and supply uncertainty (Lusiantoro et al., 2018; Sharma et al., 2019). Solér et al. (2010) identified sub-optimal information usage as a barrier to sustainable competetive advantage. A great impetus is also given in literature to information sharing, visibility, and traceability issues in PFSCs (Aung and Chang, 2014a; Balaji and Arshinder, 2016; Bosona and Gebresenbet, 2013). Bosona and Gebresenbet (2013) found quality, safety and regulatory, social, economic, and technical concerns as the major drivers for food-traceability systems in PFSCs. Zhong et al. (2015) identified the issue of inadequate knowledge in farmers, the need for information sharing with farmers, and integrating them with vendors and customers. Halloran et al. (2014) suggested information sharing and circular economy, as a possible solution to food wastage. Ineffective demand management is a significant cause of food wastage in food supply chains (Balaji and Arshinder, 2016). Demand management helps in assessing infrastructure requirements and supply management (NCCD, 2015). FSCs usually have characteristics like unmatched production, unmatched upstream-downstream lead-times, and inflexible demand and supply requirements (Adebanjo, 2009).

Other challenges like poor pre-harvest management, high operations cost, and lack of government support have been studied in the literature (Gligor et al., 2018; Gokarn and Kuthambalayan, 2017; Prakash et al., 2017). Effective legislature and government support is essential to extend sustainability across SC (Sajjad et al., 2019). Apart from these challenges, PFSCs also face challenges that are already relevant in non-perishable supply chains like poor logistics performance (Gokarn and Kuthambalayan, 2017), poor integration (Gardas et al., 2019), lack of professional skills and training (Gligor et al., 2018). Table 1, shows the challenges to sustainability in PFSCs identified from the literature and expert interviews. 


\section{Table 1}

Challenges to sustainability in PFSC

\begin{tabular}{|c|c|c|}
\hline Key Challenges & Implied Meaning & References \\
\hline $\begin{array}{l}\text { Lack of product } \\
\text { characteristics } \\
\text { and perishability } \\
\text { consideration in } \\
\text { SC planning (C1) }\end{array}$ & $\begin{array}{l}\text { Different food products need different } \\
\text { temperature ranges, handling, storage and } \\
\text { logistics capabilities. Facilities across } \\
\text { PFSCs are not designed while considering } \\
\text { product specific design considerations. }\end{array}$ & $\begin{array}{l}\text { (Aung and Chang, 2014b; } \\
\text { Gokarn and } \\
\text { Kuthambalayan, 2017; } \\
\text { Musavi et al., 2019; } \\
\text { Srivastava et al., 2015) }\end{array}$ \\
\hline $\begin{array}{l}\text { Poor demand } \\
\text { management } \\
(\mathrm{C} 2)\end{array}$ & $\begin{array}{l}\text { Since production is not demand based, it } \\
\text { results in frequent over-stocking or stock- } \\
\text { outs, causing wastage, spoilage. }\end{array}$ & $\begin{array}{l}\text { (Langroodi and Amiri, } \\
\text { 2016; Sel et al., 2018; } \\
\text { Taylor and Fearne, 2009) }\end{array}$ \\
\hline $\begin{array}{l}\text { Poor logistics } \\
\text { performance } \\
\text { (C3) }\end{array}$ & $\begin{array}{l}\text { Refrigerated vehicles required for } \\
\text { transportation of perishable products } \\
\text { consume significantly more energy as } \\
\text { compared to non-refrigerated vehicles. } \\
\text { Owing to poor logistics infrastructure and } \\
\text { service quality, lack of considering their } \\
\text { environmental impact in network design, } \\
\text { logistics performance is a major issue. }\end{array}$ & $\begin{array}{lr}\text { (Gokarn } & \text { and } \\
\text { Kuthambalayan, 2017; } & \\
\text { Song and Ko, 2016) } & \end{array}$ \\
\hline $\begin{array}{l}\text { Lack of quality } \\
\text { control (C4) }\end{array}$ & $\begin{array}{l}\text { Poor quality control at farm level as well as } \\
\text { during handling, storage and } \\
\text { transportation, causes wastage of products } \\
\text { as well as other resources. }\end{array}$ & $\begin{array}{l}\text { (Aung and Chang, 2014a; } \\
\text { Gligor et al., 2018; Song et } \\
\text { al., 2015) }\end{array}$ \\
\hline $\begin{array}{l}\text { Poor temperature } \\
\text { management } \\
\text { (C5) }\end{array}$ & $\begin{array}{l}\text { Poor temperature management limits the } \\
\text { geographical reach of the product as well as } \\
\text { product spoilage, causing economic and } \\
\text { environmental unsustainability. }\end{array}$ & $\begin{array}{l}\text { (Ali et al., 2017; Joshi et } \\
\text { al., 2009; Keivan Zokaei } \\
\text { and Simons, 2006) }\end{array}$ \\
\hline $\begin{array}{l}\text { Lack of } \\
\text { traceability and } \\
\text { supply chain } \\
\text { visibility (C6) }\end{array}$ & $\begin{array}{l}\text { Lack of traceability in PFSCs amplifies risk } \\
\text { in case of returns, recalls, spoilage, and } \\
\text { faulty batch detection. In addition, the } \\
\text { consumer may also be misinformed about } \\
\text { products regarding shelf life, production } \\
\text { location, etc. }\end{array}$ & $\begin{array}{l}\text { (Bosona and Gebresenbet, } \\
\text { 2013; Faisal and Talib, } \\
\text { 2016; Ringsberg, 2014; } \\
\text { Xiao et al., 2017) }\end{array}$ \\
\hline $\begin{array}{l}\text { Lack of } \\
\text { horizontal } \\
\text { integration of } \\
\text { farmers (C7) }\end{array}$ & $\begin{array}{l}\text { Lack of horizontal integration of farmers } \\
\text { makes the supply disaggregated and } \\
\text { fragmented. Poor integration of farmers } \\
\text { with retailers and wholesalers leads to } \\
\text { economic and social unsustainability. }\end{array}$ & $\begin{array}{l}\text { (Gardas et al., 2018; } \\
\text { Gligor et al., 2018; Gokarn } \\
\text { and Kuthambalayan, } \\
\text { 2017; Negi and Anand, } \\
\text { 2016; Rais and Sheoran, } \\
\text { 2015) }\end{array}$ \\
\hline $\begin{array}{l}\text { Lack of } \\
\text { information and } \\
\text { communication } \\
\text { tools (C8) }\end{array}$ & $\begin{array}{l}\text { Enabling information flow through ICTs } \\
\text { improves the productivity, income of } \\
\text { farmers and overall sustainability of } \\
\text { PSFCs. }\end{array}$ & $\begin{array}{l}\text { (Keivan Zokaei and } \\
\text { Simons, 2006; Routroy } \\
\text { and Behera, 2017) }\end{array}$ \\
\hline $\begin{array}{l}\text { Poor pre-harvest } \\
\text { management } \\
\text { (C9) }\end{array}$ & $\begin{array}{l}\text { Pre-harvest conditions like irrigation } \\
\text { techniques, quality seeds, time of harvest, } \\
\text { significantly influence the quality and the } \\
\text { holding life, as well as the sustainability of } \\
\text { PFSC. }\end{array}$ & $\begin{array}{l}\text { (Gokarn and } \\
\text { Kuthambalayan, 2017) }\end{array}$ \\
\hline
\end{tabular}




\begin{tabular}{|l|l|l|}
\hline $\begin{array}{l}\text { Infrastructure } \\
\text { issues (C10) }\end{array}$ & $\begin{array}{l}\text { Power cuts, poor infrastructure } \\
\text { connectivity to farm, and lack of highways, } \\
\text { roads cause unexpected delays in delivery, } \\
\text { loss of shelf life and hamper economic } \\
\text { activities throughout the PFSC. }\end{array}$ & $\begin{array}{l}\text { (Aiying et al., 2011; Balaji } \\
\text { and Arshinder, 2016; } \\
\text { Gligor et al., 2018; Joshi et } \\
\text { al., 2009; Raut et al., 2018) }\end{array}$ \\
\hline $\begin{array}{l}\text { Uncertain market } \\
\text { prices (C11) }\end{array}$ & $\begin{array}{l}\text { Fluctuating prices directly cause loss of } \\
\text { sales, and poor profitability and economic } \\
\text { sustainability for the organizations. }\end{array}$ & $\begin{array}{l}\text { (Gokarn } \\
\text { Kuthambalayan, 2017; Liu } \\
\text { et al., 2018) }\end{array}$ \\
\hline $\begin{array}{l}\text { Poor cold chain } \\
\text { infrastructure } \\
\text { (C12) }\end{array}$ & $\begin{array}{l}\text { Cold chain support is critical in PFSCs. } \\
\text { Unavailability and poor cold chain support } \\
\text { is a major cause of PHL and supply chain } \\
\text { unsustainability in PFSC. }\end{array}$ & $\begin{array}{l}\text { (Gligor et al., 2018; Joshi } \\
\text { et al., 2009; Kohli, 2012; } \\
\text { Anand, 2015; Negi and } \\
\text { 2018; Raut et al., } \\
\text { Viswanadham, } \\
\text { 2006) }\end{array}$ \\
\hline $\begin{array}{l}\text { Lack of } \\
\text { government } \\
\text { regulation } \\
\text { support (C13) }\end{array}$ & $\begin{array}{l}\text { Government policy and regulatory support } \\
\text { is essential to enable sustainability in } \\
\text { PFSCs. }\end{array}$ & $\begin{array}{l}\text { (Gligor et al., 2018; Joshi } \\
\text { et al., 2009; Kohli, 2012) }\end{array}$ \\
\hline
\end{tabular}

\subsection{Research Methods and PFSCs}

Decision support research related to sustainability and FSCs have attracted many scholarly contributions and a range of tools and methodologies have been used. Both qualitative and quantitative research methodologies have been used in this domain. Various methodologies applied to such problems related to sustainability and PFSCs are demonstrated in Table 2.

\section{Table 2.}

Research methods in sustainability related FSC/PFSC literature

\begin{tabular}{|c|c|c|}
\hline Author & Focus Area & Research Method \\
\hline $\begin{array}{l}\text { (Chen et al., } \\
\text { 2018) }\end{array}$ & $\begin{array}{l}\text { Socially responsible sustainable supplier selection } \\
\text { and SC development. }\end{array}$ & TISM-ANP \\
\hline $\begin{array}{l}\text { (Faisal and Talib, } \\
\text { 2016) }\end{array}$ & Factors to implement traceability in the FSCs. & ISM-MICMAC \\
\hline $\begin{array}{l}\text { (Chauhan et al., } \\
\text { 2019) }\end{array}$ & $\begin{array}{l}\text { Factors to select efficient sustainable agri-produce } \\
\text { supply chain. }\end{array}$ & $\begin{array}{l}\text { ISM-DEMATEL- } \\
\text { ANP }\end{array}$ \\
\hline $\begin{array}{l}\text { (Gokarn and } \\
\text { Kuthambalayan, } \\
\text { 2017) }\end{array}$ & Challenges to reduce FSC wastages. & EFA, ISM \\
\hline (Raut et al., 2019) & $\begin{array}{l}\text { Green oriented performance indicators in agro- } \\
\text { sector. }\end{array}$ & $\begin{array}{l}\text { EFA, CFA and } \\
\text { SEM }\end{array}$ \\
\hline $\begin{array}{l}\text { (Farooque et al., } \\
\text { 2019) }\end{array}$ & Barriers to integrating circular economy in FSCs. & DEMATEL \\
\hline (Lau et al., 2018) & $\begin{array}{l}\text { Identification of non-compensating sub-criteria of } \\
\text { food safety. }\end{array}$ & $\begin{array}{l}\text { FAHP- TOPSIS- } \\
\text { ELECTRE }\end{array}$ \\
\hline $\begin{array}{l}\text { (Ghadge et al., } \\
2017)\end{array}$ & Challenges to adopting green practices in FSCs. & AHP \\
\hline (Raut, 2019) & $\begin{array}{l}\text { Criteria and sub-criteria to reduce losses in fruit \& } \\
\text { vegetables SCs. }\end{array}$ & $\begin{array}{l}\text { F-DEMATEL, F- } \\
\text { AHP }\end{array}$ \\
\hline
\end{tabular}




\begin{tabular}{|lll|l|l|}
\hline $\begin{array}{l}\text { Zhong } \\
2015)\end{array}$ & et & al., & $\begin{array}{l}\text { Need for information dissemination and strategies } \\
\text { to enable it among vegetable farmers and vendors }\end{array}$ & SEM \\
\hline $\begin{array}{l}\text { (Deng } \\
2019)\end{array}$ & et & al., & $\begin{array}{l}\text { Risk propagation and countermeasures for } \\
\text { sustainability in perishable products SC. }\end{array}$ & $\begin{array}{l}\text { Tropos-Goal- } \\
\text { Risk framework }\end{array}$ \\
\hline
\end{tabular}

Various hybrid approaches successfully solve complex decision making. However, the common defects of these methods are that evaluation criteria are generally not inclusive and interrelationships among factors are unclear and obscure (Chen et al., 2018). ISM is a wellestablished methodology to analyse the contextual inter-relationships among factors and develop structural understanding of the factors included in the research (Agi and Nishant, 2017; Chauhan et al., 2019; Prakash et al., 2017). The integrated ISM-ANP approach uses the contextual relationship developed from the ISM model as inputs to identify the pairwise comparison sets in ANP. To mollify the input necessities of ANP and reduce the computations in the ANP methodology, ISM was integrated with ANP (Govindan et al., 2016). ANP, is used in Multi-Criteria Decision Making (MCDM) problems to rank variables. ANP can be very useful in knowing criticality and prioritizing the factors and, thus, finds application in the current problem on PFSC. Given that the theoretical understanding of challenges relevant to sustainability of PFSC in developing countries is still not fully developed, ISM-ANP fulfils the methodological requirements of this research. Thus, the present work finds use of ISM-ANP integrated framework appropriate for analysing the current research problem.

\subsection{Gap analysis and research motivation.}

The key research gaps used in the present work to formulate a research problem are as follows:

- Lack of TBL view of challenges to sustainability in PFSCs.

Sustainability of PFSCs need to be evaluated on the triple bottom line of environmental, economic and societal challenges to the various members of PFSC - farmers, managers, organizations as well as the customers. The majority of the sustainability related literature in PFSCs ia industry specific like dairy (Ghadge et al., 2017), meat (Sgarbossa and Russo, 2017), fruit and vegetables (Raut, 2019), etc.; and consider specific issues like wastage (Balaji and Arshinder, 2016; Negi and Anand, 2016), logistics barriers (Raut and Gardas, 2018), PHL (Gardas et al., 2018; Hodges et al., 2011; Raut et al., 2018). A holistic decision framework to model challenges to the TBL view of sustainability in necessary to fill this gap.

- Lack of literature to evaluate the priority of TBL based challenges to sustainability in PFSCs.

Preference is a central concept of decision theory. However, literature identifies an insufficient theoretical support to managerial decision making based on prioritizing sustainable dimensions 
(Davis-Sramek et al., 2018). While a general inclination towards economic dimension is seen in practice, a win-win situation which supports ecological and social perspectives to be balanced with economy is supported in the literature. Thus, decision support to realize priorities of challenges to sustainability in PFSCs is a necessary gap to be addressed.

- Lack of research on challenges to sustainability of PFSCs in developing countries.

Sustainable production and consumption in FSCs is a global issue as well as a necessity (Govindan, 2018a). Various studies report prevalent unsustainable practices in PFSCs (Bourlakis and Matopoulos, 2010; De Hooge et al., 2018). However, the less developed countries, which account for $80 \%$ of global population and $99 \%$ of population growth, are less studied. Sustainability challenges of PFSCs in developing countries are different from developed countries and not fully understood (Hodges et al., 2011; Shirish Sangle, 2010). Various studies have identified a lack of research in PFSCs in the context of developing countries (Balaji and Arshinder, 2016; Shukla and Jharkharia, 2013).

\section{Research methodology}

At the first stage, a list of 13 key challenges relevant to PFSCs, as shown in Table 1, were identified from the literature. The key challenges have been identified through a literature review by searching for various combinations of keywords like, "perishable + supply chain + sustainability"; "perishable + challenges + supply chain"; "perishable + food +supply chain + challenges"; "perishable + supply + risks"; "agri + Supply chain + issues/challenges/barriers/risks"; "food + supply chain + issues/challenges/barriers/risks". The keywords were selected based on the identified key research themes in various literature and reviews studied on a preliminary basis. Fig. 2, describes the theoretical flow diagram of this work. 


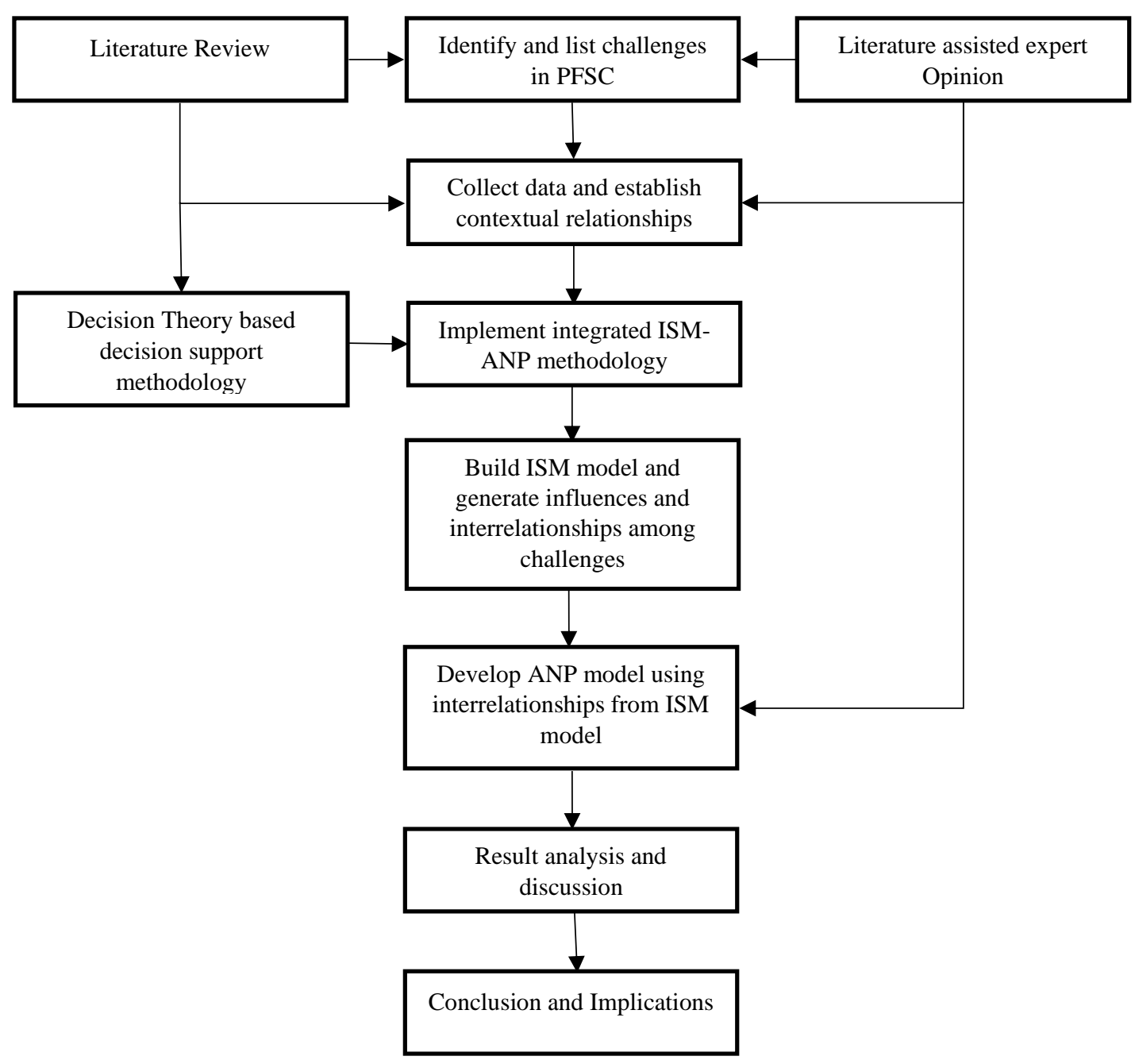

Fig. 2. Theoretical flow diagram of this work

Key challenges are identified through the expert assisted literature survey. The interviews conducted with the industrial experts provided the key insights into the challenges; to finalize 13 key challenges in PFSCs in the Indian context, as well as to understand their contextual relationships. These challenges were categorized into: SC planning, SC performance, SC competence, and external issues. The challenges are further analysed using an ISM-ANP integrated methodology. The results from ANP prioritizes and improves the understanding of the results from ISM (Bhadani et al., 2016). Finally, to better understand the overall criticality of the identified challenges, an integrated approach is followed by multiplying the ANP score of the challenges with the ISM level, to generate the final priority scores of the challenges. This is a novel approach towards integrating ISM and ANP results for joint identification of the importance of the factors using the results from both the methodologies. 


\subsection{Interpretive Structural Modelling (ISM)}

The ISM is a well-supported and established technique used by various researchers (Balaji and Arshinder, 2016; Mangla et al., 2018, 2014; Tyagi et al., 2017, 2015). It is robust and an interactive methodology that depends on the adept knowledge of field experts (Warfield, 1974) and is helpful in understanding the influences and interdependencies of the challenges. The ISM technique follows the following steps:

1. Formation of a structural-self-interaction-matrix (SSIM).

2. Development of an initial-reachability-matrix (IRM) from SSIM.

3. This IRM is checked for the transitivity condition and further transformed to satisfy transitivity.

4. Development of the final-reachability-matrix (FRM) and partitioning it in various levels.

5. Formation of a digraph using the partitioned levels, removing all the transitivity links.

6. Finalizing of the ISM model by conceptual validation of the contextual relationships and making the desired changes using expert views.

7. Derive the driving-dependence power of each challenge from the FRM.

8. Construct a driving-dependence diagram for MICMAC using the FRM.

The MICMAC analysis is done to analyze the challenges to sustainability in PFSCs based on the driving-dependence of each challenge, and to further validate the results of the ISM. The challenges are segregated in four regions: independent, linkage, dependent, and autonomous.

\subsection{Analytic Network Process (ANP)}

The ANP is also a well-supported and established technique; it has been applied in several domains like, rural telecom (Bhadani et al., 2016), 3PL selection (Thakkar et al., 2005), and sustainable supply chain (Faisal et al., 2017). It considers a network structure of the problem and, hence, results in more accurate findings (Govindan et al., 2016; Zhang, 2017). The ANP encapsulates interrelations and dependencies of a higher level of hierarchy from lower levels as well as across the same level of the hierarchy (Hosseini et al., 2013). A decision maker fills pairwise comparison matrices on a scale of 1-9. Based on these pairwise comparison matrices, priorities are generated for different alternatives as well as criteria. The ANP is applied using the steps as follows:

1. Formation of ANP model with goal, cluster of criteria, sub-criteria elements of clusters, connections representing interdependencies, and interrelationships. The 
interrelationships specified in the model have previously been identified in the ISM model.

2. Pairwise-comparisons of elements using the interrelationships found from the ISM model.

3. The local priority weights from all the pairwise-comparisons found out in the previous step are used to generate the super-matrix.

4. The relative weights of each cluster of criteria concerning other criteria are found and multiplied in the respective section of the super-matrix to obtain the weighted normalized super-matrix. It is raised to the limiting powers and gives the global priorities of the system.

\section{Data analysis and results}

\subsection{Data collection and finalization of challenges}

Brainstorming sessions were held with nine experts working in the field of PFSCs to collect data as well as discuss challenges in PFSCs. The profile of experts, as well as their business role in PFSCs, is as shown in Table 3.

Table 3

Experts and Organizations

\begin{tabular}{|c|c|c|c|c|}
\hline $\begin{array}{l}\text { Expert } \\
\text { No. }\end{array}$ & $\begin{array}{l}\text { Experience } \\
\text { in Years }\end{array}$ & $\begin{array}{l}\text { Business Role in Supply } \\
\text { Chain }\end{array}$ & Designation & $\begin{array}{c}\text { Annual } \\
\text { Turnover of } \\
\text { Organization }\end{array}$ \\
\hline 1 & 28 & $\begin{array}{l}\text { Milk procurement, processing } \\
\text { and marketing }\end{array}$ & $\begin{array}{l}\text { Deputy-General } \\
\text { Manager }\end{array}$ & 8000 Crore INR \\
\hline 2 & 23 & Milk distribution and logistics & Senior Manager & 8000 Crore INR \\
\hline 3 & 19 & $\begin{array}{l}\text { Fruits procurement and } \\
\text { marketing }\end{array}$ & $\begin{array}{l}\text { Managing } \\
\text { Director }\end{array}$ & 35 Crore INR \\
\hline 4 & 7 & $\begin{array}{l}\text { Distribution of fruits and } \\
\text { vegetables }\end{array}$ & City Head & 200 Crore INR \\
\hline 5 & 25 & $\begin{array}{l}\text { Implementing } \\
\text { government schemes in } \\
\text { horticulture sector }\end{array}$ & $\begin{array}{l}\text { Assistant } \\
\text { Commissioner }\end{array}$ & Not applicable \\
\hline 6 & 20 & $\begin{array}{lr}\text { Implementing } & \text { state } \\
\text { government schemes } & \text { in } \\
\text { horticulture sector } & \\
\end{array}$ & $\begin{array}{l}\text { Horticulture } \\
\text { Commissioner }\end{array}$ & Not applicable \\
\hline 7 & 30 & $\begin{array}{l}\text { Advising government on } \\
\text { policies for cold chain } \\
\text { development }\end{array}$ & $\mathrm{CEO}$ & Not applicable \\
\hline 8 & 28 & Academics & Professor & Not applicable \\
\hline 9 & 5 & Academics & $\begin{array}{l}\text { Assistant } \\
\text { Professor }\end{array}$ & Not applicable \\
\hline
\end{tabular}


The experts were initially contacted through emails and telephone; later, personal meetings and site visits were arranged with all of them. Interviews with the experts were conducted by visiting the relevant industries physically. Each interview lasted for almost 45-60 minutes, the average years of experts' experience were 20.55. Experts belonged to five different organizations, therefore five interviews by pooling the experts and two sessions of interview in each pool were conducted. Experts 1 and 2 belonged to a company in the dairy industry. Expert 3 belonged to a company with business in milk procurement, fruits production, training, procurement and marketing. Expert 4 belonged to a company that provided third-party logistics services for fruits and vegetables. Experts 5, 6, and 7 belonged to government agencies that provided consultancy and policy support to organizations as well as farmers. Experts 8 and 9 were from the academic domain with research experience in SCs and PFSCs. A range of challenges related to the PFSC have been discussed in the literature. A portfolio of commonly cited, generic challenges in PFSCs was generated, out of which 15 challenges were selected. A list of the 15 generic challenges selected initially is shown in Appendix A. Based on the portfolio of challenges selected from the literature, semi-structured interviews with experts were conducted to generate a state-of-the-art vision of the current issues and challenges in PFSCs in India. From the list of challenges, the expert suggested removing five challenges and adding three new challenges to the study. The resultant 13 challenges, as shown in Table 1, are then discussed with academic experts to understand their relevance to PFSCs in India and collect data as required in ISM-ANP methodology.

\subsection{ISM application}

The contextual relationship between different challenges are modelled into the SSIM, shown in Table 4. The code letters V, A, X, O are used to show the different contextual relationships and the respective meanings as follows:

$\mathrm{V}$ - Issues (i) causes/enhances issue (j), but not vice-versa.

A- Issues (j) causes/enhances issue (i), but not vice-versa.

$\mathrm{X}$ - Issues (i) and (j) cause/enhance each other.

O- no inter-relation between issue (i) and (j).

Table 4

SSIM of contextual relationship between challenges

\begin{tabular}{|l|l|l|l|l|l|l|l|l|l|l|l|l|l|l|}
\hline & 1 & 2 & 3 & 4 & 5 & 6 & 7 & 8 & 9 & 10 & 11 & 12 & 13 & I \\
\hline 1. Lack of Perishability Related SC Design & - & V & V & V & O & O & O & A & O & A & O & X & A \\
\hline 2. Poor Demand Management & & - & O & A & O & A & A & O & A & O & X & A & O \\
\hline 3. Poor Logistics Performance & & & - & V & O & O & A & O & A & A & V & A & O \\
\hline
\end{tabular}




\begin{tabular}{|c|c|c|c|c|c|c|c|c|c|c|}
\hline 4. Lack of Quality Control & - & A & $\mathrm{X}$ & $\mathrm{O}$ & A & $\mathrm{V}$ & A & $\mathrm{X}$ & A & A \\
\hline 5. Poor Temperature Control & & - & $\mathrm{O}$ & $\mathrm{O}$ & $\mathrm{O}$ & $\mathrm{O}$ & $\mathrm{A}$ & $\mathrm{V}$ & A & $\mathrm{O}$ \\
\hline 6. Lack of Traceability and Supply Chain Visibility & & & - & A & $\mathrm{O}$ & $\mathrm{X}$ & $\mathrm{O}$ & $\mathrm{V}$ & A & A \\
\hline 7. Lack of Horizontal Integration of Farmers & & & & - & A & $\mathrm{X}$ & A & $\mathrm{V}$ & A & $\mathrm{X}$ \\
\hline 8. Poor Pre Harvest Management & & & & & - & A & $\mathrm{O}$ & $\mathrm{V}$ & $\mathrm{O}$ & A \\
\hline 9. Poor Use of ICT & & & & & & - & $\mathrm{O}$ & $\mathrm{V}$ & $\mathrm{O}$ & $\mathrm{V}$ \\
\hline 10. Infrastructure Issues & & & & & & & - & $\mathrm{V}$ & $\mathrm{O}$ & A \\
\hline 11. Uncertain Market Prices & & & & & & & & - & A & $\mathrm{O}$ \\
\hline 12. Poor Cold Chain Infrastructure & & & & & & & & & - & A \\
\hline 13. Lack of Government Regulation and Support & & & & & & & & & & - \\
\hline
\end{tabular}

The IRM is formed from the SSIM. The IRM was checked for the transitivity rule, and the FRM was developed, as shown in Table 5. According to the transitivity rule, "A" enhances "B" and "B" enhances " $\mathrm{C}$," then "A" will also enhance "C".

\section{Table 5}

Final reachability matrix (FRM)

\begin{tabular}{|l|l|l|l|l|l|l|l|l|l|l|l|l|l|l|}
\hline & $\mathbf{1}$ & $\mathbf{2}$ & $\mathbf{3}$ & $\mathbf{4}$ & $\mathbf{5}$ & $\mathbf{6}$ & $\mathbf{7}$ & $\mathbf{8}$ & $\mathbf{9}$ & $\mathbf{1 0}$ & $\mathbf{1 1}$ & $\mathbf{1 2}$ & $\mathbf{1 3}$ & Driving Power \\
\hline $\begin{array}{l}\text { 1. Lack of Perishability Related SC } \\
\text { Design }\end{array}$ & 1 & 1 & 1 & 1 & 0 & $\mathrm{~A}$ & $\mathrm{~A}$ & 0 & $\mathrm{~A}$ & 0 & $\mathrm{~A}$ & 1 & 0 & $\mathbf{9}$ \\
\hline 2. Poor Demand Management & 0 & 1 & 0 & 0 & 0 & 0 & 0 & 0 & 0 & 0 & 1 & 0 & 0 & $\mathbf{2}$ \\
\hline 3. Poor Logistics Performance & 0 & $\mathrm{~A}$ & 1 & 1 & 0 & $\mathrm{~A}$ & 0 & 0 & $\mathrm{~A}$ & 0 & 1 & 0 & 0 & $\mathbf{6}$ \\
\hline 4. Lack of Quality Control & $\mathrm{A}$ & 1 & $\mathrm{~A}$ & 1 & 0 & 1 & $\mathrm{~A}$ & $\mathrm{~A}$ & 1 & 0 & 1 & 0 & $\mathrm{~A}$ & $\mathbf{1 0}$ \\
\hline 5. Poor Temperature Control & 0 & $\mathrm{~A}$ & 0 & 1 & 1 & $\mathrm{~A}$ & 0 & 0 & $\mathrm{~A}$ & 0 & 1 & 0 & 0 & $\mathbf{6}$ \\
\hline $\begin{array}{l}\text { 6. Lack of Traceability and Supply Chain } \\
\text { Visibility }\end{array}$ & 0 & 1 & $\mathrm{~A}$ & 1 & 0 & 1 & $\mathrm{~A}$ & $\mathrm{~A}$ & 1 & 0 & 1 & 0 & $\mathrm{~A}$ & $\mathbf{9}$ \\
\hline $\begin{array}{l}\text { 7. Lack of Horizontal Integration of } \\
\text { Farmers }\end{array}$ & $\mathrm{A}$ & 1 & 1 & $\mathrm{~A}$ & 0 & 1 & 1 & $\mathrm{~A}$ & 1 & $\mathrm{~A}$ & 1 & $\mathrm{~A}$ & 1 & $\mathbf{1 2}$ \\
\hline 8. Poor Pre Harvest Management & 1 & $\mathrm{~A}$ & $\mathrm{~A}$ & 1 & 0 & $\mathrm{~A}$ & 1 & 1 & $\mathrm{~A}$ & 0 & 1 & $\mathrm{~A}$ & $\mathrm{~A}$ & $\mathbf{1 1}$ \\
\hline 9. Poor Use of ICT & $\mathrm{A}$ & 1 & 1 & $\mathrm{~A}$ & 0 & 1 & 1 & 1 & 1 & $\mathrm{~A}$ & 1 & $\mathrm{~A}$ & 1 & $\mathbf{1 2}$ \\
\hline 10. Infrastructure Issues & 1 & $\mathrm{~A}$ & 1 & 1 & 1 & $\mathrm{~A}$ & 1 & 0 & $\mathrm{~A}$ & 1 & 1 & $\mathrm{~A}$ & $\mathrm{~A}$ & $\mathbf{1 2}$ \\
\hline 11. Uncertain Market Prices & 0 & 1 & $\mathrm{~A}$ & 1 & 0 & $\mathrm{~A}$ & 0 & 0 & $\mathrm{~A}$ & 0 & 1 & 0 & 0 & $\mathbf{6}$ \\
\hline 12. Poor Cold Chain Infrastructure & 1 & 1 & 1 & 1 & 1 & 1 & 1 & 0 & $\mathrm{~A}$ & 0 & 1 & 1 & $\mathrm{~A}$ & $\mathbf{1 1}$ \\
\hline $\begin{array}{l}\text { 13. Lack of Government Regulation and } \\
\text { Support }\end{array}$ & 1 & $\mathrm{~A}$ & $\mathrm{~A}$ & 1 & $\mathrm{~A}$ & 1 & 1 & 1 & $\mathrm{~A}$ & 1 & $\mathrm{~A}$ & 1 & 1 & $\mathbf{1 3}$ \\
\hline
\end{tabular}

The final reachability matrix is partitioned to develop a hierarchy of the challenges. The antecedent, reachability, and intersection sets were obtained for each element. At this stage, all the factors which have the same intersection and reachability set will be on the same level and will not reach any other factor above them. Thus, the challenges whose reachability set and intersection set have the same values are allotted level 1. Level 1 challenges are removed from the successive iterations. The same process is repeated until all the challenges are allotted levels, as shown in Table 6.

\section{Table 6}

Level partition for ISM model

\begin{tabular}{|c|c|c|c|c|c|c|c|c|c|c|c|c|c|c|c|c|c|}
\hline & 1 & 2 & 3 & 4 & 5 & 6 & 7 & 8 & 9 & 10 & 11 & 12 & 13 & Reachability & Antecedent & Intersection & Level \\
\hline 1. & 1 & 1 & 1 & 1 & 0 & $1 *$ & $1 *$ & 0 & $1^{*}$ & 0 & $1 *$ & 1 & 0 & $\begin{array}{l}1,2,3,4,6,7,9,11, \\
12\end{array}$ & $\begin{array}{l}1,4,5,7,8,9,10,1 \\
2,13\end{array}$ & $1,4,7,9,12$ & III \\
\hline 2. & 0 & 1 & 0 & 0 & 0 & 0 & 0 & 0 & 0 & 0 & 1 & 0 & 0 & 2,11 & $\begin{array}{l}1,2,3,4,5,6,7,8,9 \\
10,11,12,13\end{array}$ & 2,11 & I \\
\hline 3. & 0 & $1 *$ & 1 & 1 & 0 & $1 *$ & 0 & 0 & $1 *$ & 0 & 1 & 0 & 0 & $2,3,4,6,9,11$ & $\begin{array}{l}1,3,4,5,6,7,8,9,1 \\
0,11,12,13\end{array}$ & $3,4,6,9,11$ & II \\
\hline 4. & $1^{*}$ & 1 & $1^{*}$ & 1 & 0 & 1 & $1 *$ & $1 *$ & 1 & 0 & 1 & 0 & $1 *$ & $\begin{array}{l}1,2,3,4,6,7,8,9, \\
11,13\end{array}$ & $\begin{array}{l}1,3,4,5,6,7,8,9,1 \\
0,11,12,13\end{array}$ & $\begin{array}{l}1,3,4,6,7,8,9, \\
11,13,\end{array}$ & II \\
\hline 5. & 0 & $1 *$ & 0 & 1 & 1 & $1 *$ & 0 & 0 & $1^{*}$ & 0 & 1 & 0 & 0 & $2,4,5,6,9,11$ & $5,10,12,13$ & 5 & III \\
\hline
\end{tabular}




\begin{tabular}{|c|c|c|c|c|c|c|c|c|c|c|c|c|c|c|c|c|c|}
\hline 6. & 0 & 1 & $1^{*}$ & 1 & 0 & 1 & $1 *$ & $1 *$ & 1 & 0 & 1 & 0 & $1 *$ & $\begin{array}{l}2,3,4,6,7,8,9,11, \\
13\end{array}$ & $\begin{array}{l}1,3,4,5,6,7,8,9,1 \\
0,11,12,13\end{array}$ & $\begin{array}{l}3,4,6,7,8,9,11 \\
13\end{array}$ & II \\
\hline 7. & $1^{*}$ & 1 & 1 & $1^{*}$ & 0 & 1 & 1 & $1^{*}$ & 1 & $1^{*}$ & 1 & $1^{*}$ & 1 & $\begin{array}{l}1,2,3,4,6,7,8,9,1 \\
0,11,12,13\end{array}$ & $\begin{array}{l}1,4,6,7,8,9,10,1 \\
2,13\end{array}$ & $\begin{array}{l}1,4,6,7,8,9,10 \\
, 12,13 \\
\end{array}$ & III \\
\hline 8. & 1 & $1 *$ & $1 *$ & 1 & 0 & $1^{*}$ & 1 & 1 & $1 *$ & 0 & 1 & $1 *$ & $1 *$ & $\begin{array}{l}1,2,3,4,6,7,8,9 \\
11,12,13\end{array}$ & $4,6,7,8,9,13$ & $4,6,7,8,9,13$ & IV \\
\hline 9. & $1 *$ & 1 & 1 & $1 *$ & 0 & 1 & 1 & 1 & 1 & $1 *$ & 1 & $1 *$ & 1 & $\begin{array}{l}1,2,3,4,6,7,8,9,1 \\
0,11,12,13\end{array}$ & $\begin{array}{l}1,3,4,5,6,7,8,9,1 \\
0,11,12,13\end{array}$ & $\begin{array}{l}1,3,4,6,7,8,9, \\
10,11,12,13\end{array}$ & II \\
\hline 10. & 1 & $1^{*}$ & 1 & 1 & 1 & $1^{*}$ & 1 & 0 & $1^{*}$ & 1 & 1 & $1 *$ & $1 *$ & $\begin{array}{l}1,2,3,4,5,6,7,9,1 \\
0,11,12,13\end{array}$ & $7,9,10,13$ & $7,9,10,13$ & $\mathbf{V}$ \\
\hline 11. & 0 & 1 & $1 *$ & 1 & 0 & $1 *$ & 0 & 0 & $1 *$ & 0 & 1 & 0 & 0 & $2,3,4,6,9,11$ & $\begin{array}{l}1,2,3,4,5,6,7,8,9 \\
10,11,12,13\end{array}$ & $2,3,4,6,9,11$ & $\mathbf{I}$ \\
\hline 12. & 1 & 1 & 1 & 1 & 1 & 1 & 1 & 0 & $1 *$ & 0 & 1 & 1 & $1^{*}$ & $\begin{array}{l}1,2,3,4,5,6,7,9 \\
11,12,13\end{array}$ & $\begin{array}{l}1,5,7,8,9,10,12, \\
13\end{array}$ & $1,5,7,9,12,13$ & III \\
\hline 13. & 1 & $1 *$ & $1 *$ & 1 & $1 *$ & 1 & 1 & 1 & $1^{*}$ & 1 & $1^{*}$ & 1 & 1 & $\begin{array}{l}1,2,3,4,5,6,7,8,9 \\
10,11,12,13\end{array}$ & $4,6,7,8,9,10,13$ & $\begin{array}{l}4,6,7,8,9,10,1 \\
3\end{array}$ & $\mathbf{V}$ \\
\hline
\end{tabular}

The digraph of the final hierarchical structure, based on the level partition of the ISM model for challenges to sustainability in PFSCs, is depicted in Fig 3.

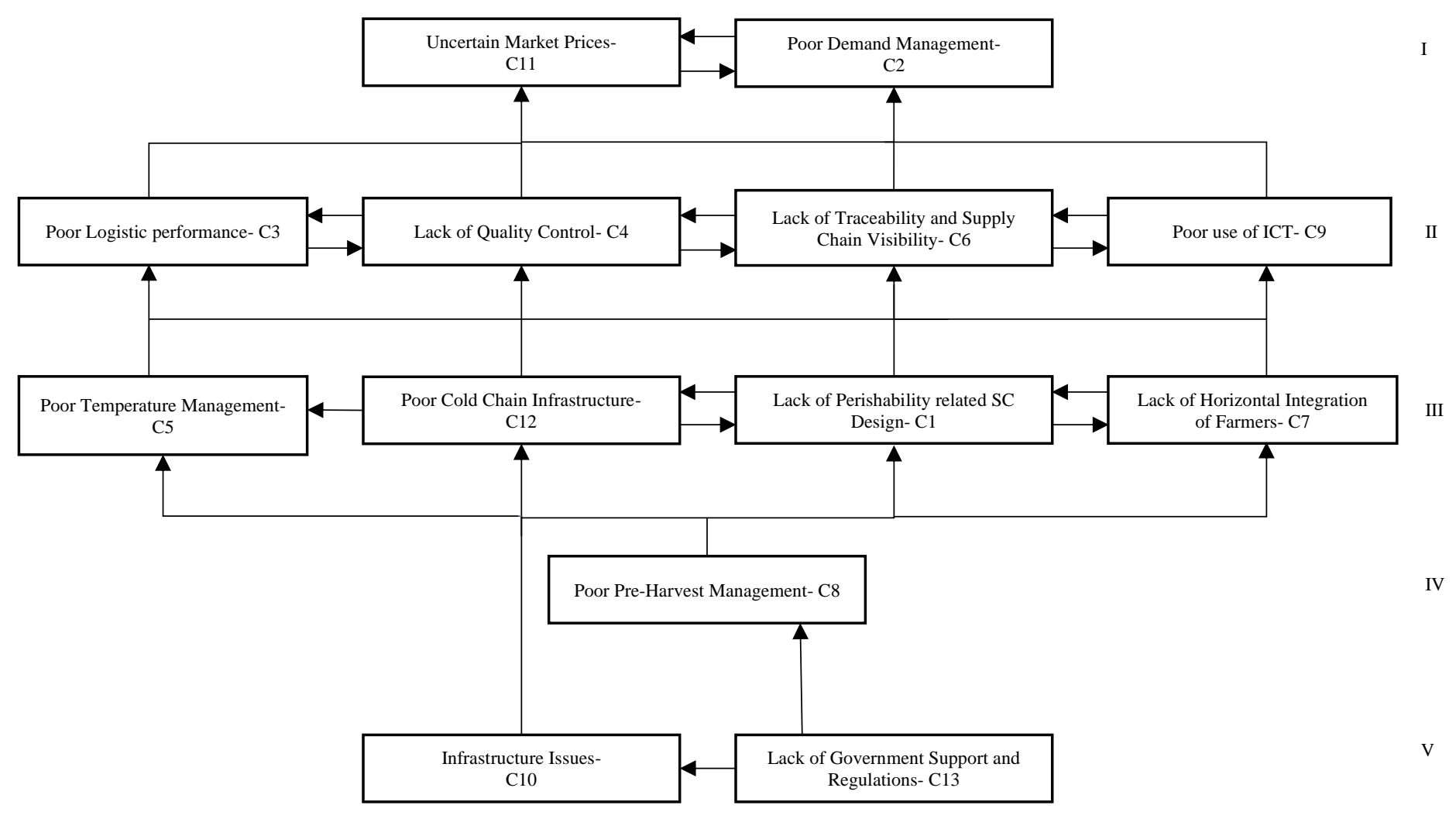

Fig. 3. ISM model for challenges to sustainability in PFSC

The ISM model, thus generated, will be used further to identify the linkages in the ANP model developed in the later stages. The directed relationships shown in the hierarchy produced, helps in identifying the interrelationships to be used in ANP modelling.

\subsection{MICMAC analysis}

MICMAC analysis, first developed by Duperrin in 1973 (Duperrin and Godet, 1973), is used for validating the results of ISM. The analysis divides the challenges into four regions: independent, linkage, dependent, and autonomous. The driving and dependence of challenges, 
as found in Table 5, is used for MICMAC analysis. Infrastructure issues (C10) and poor preharvest management (C8) are identified in the independent region, they have high driving and low dependence. They may be interpreted as the "key challenges" to sustainability in PFSCs. Poor demand management (C2), uncertain market prices (C11) and poor logistics performance (C3) are identified in the dependent region, and may be interpreted as "output challenges" indicating poor sustainability in PFSCs. Poor cold chain infrastructure (C12), lack of government regulation and support (C13), lack of horizontal integration of farmers (C7), lack of perishability related SC design (C1), poor use of ICT (C9), lack of quality control (C4), lack of traceability and supply chain visibility (C6), are identified in the linkage region. Only one challenge, poor temperature control (C5), is in the autonomous region.

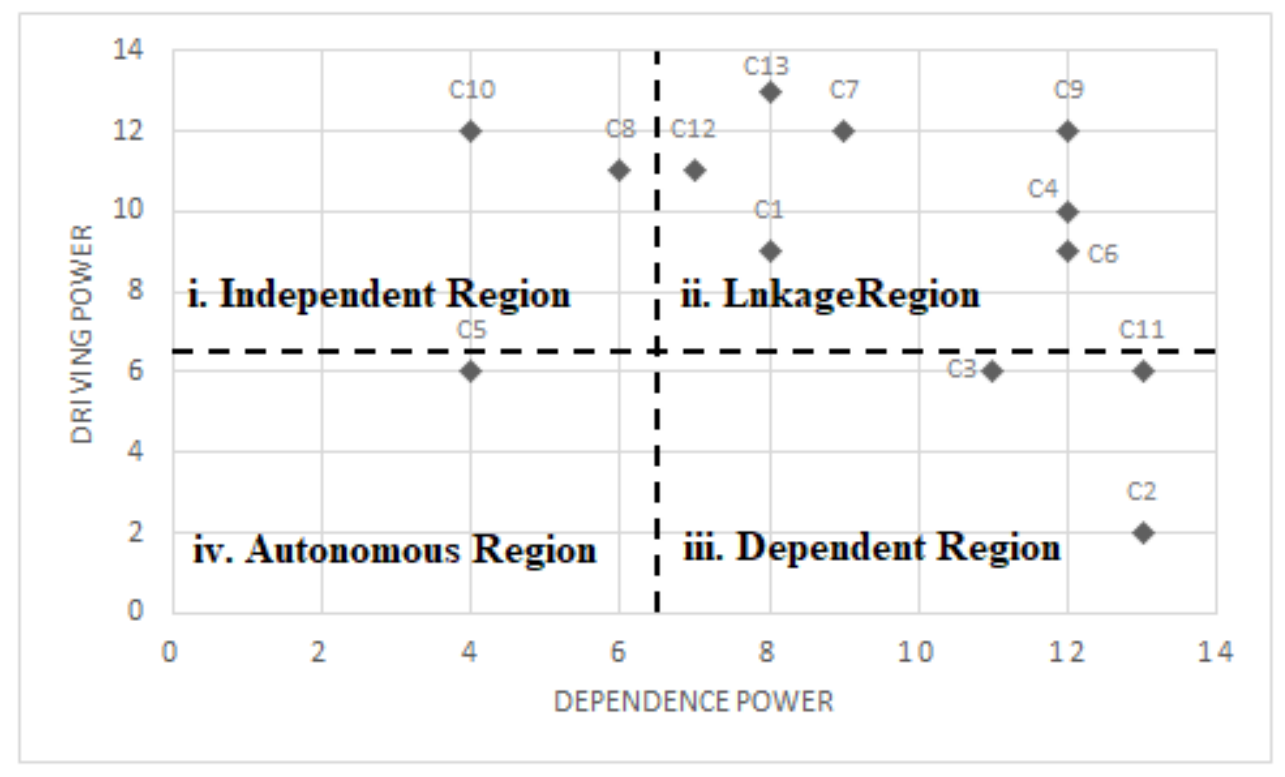

Fig. 4. MICMAC analysis of challenges to sustainability in PFSCs

\subsection{ANP modelling}

The digraph, as shown in Fig 3, as well as the contextual relationship matrix in ISM are used as an input to generate the interrelationships among criteria elements of the model to structure the problem in a network form ANP model, as illustrated in Fig. 5. 


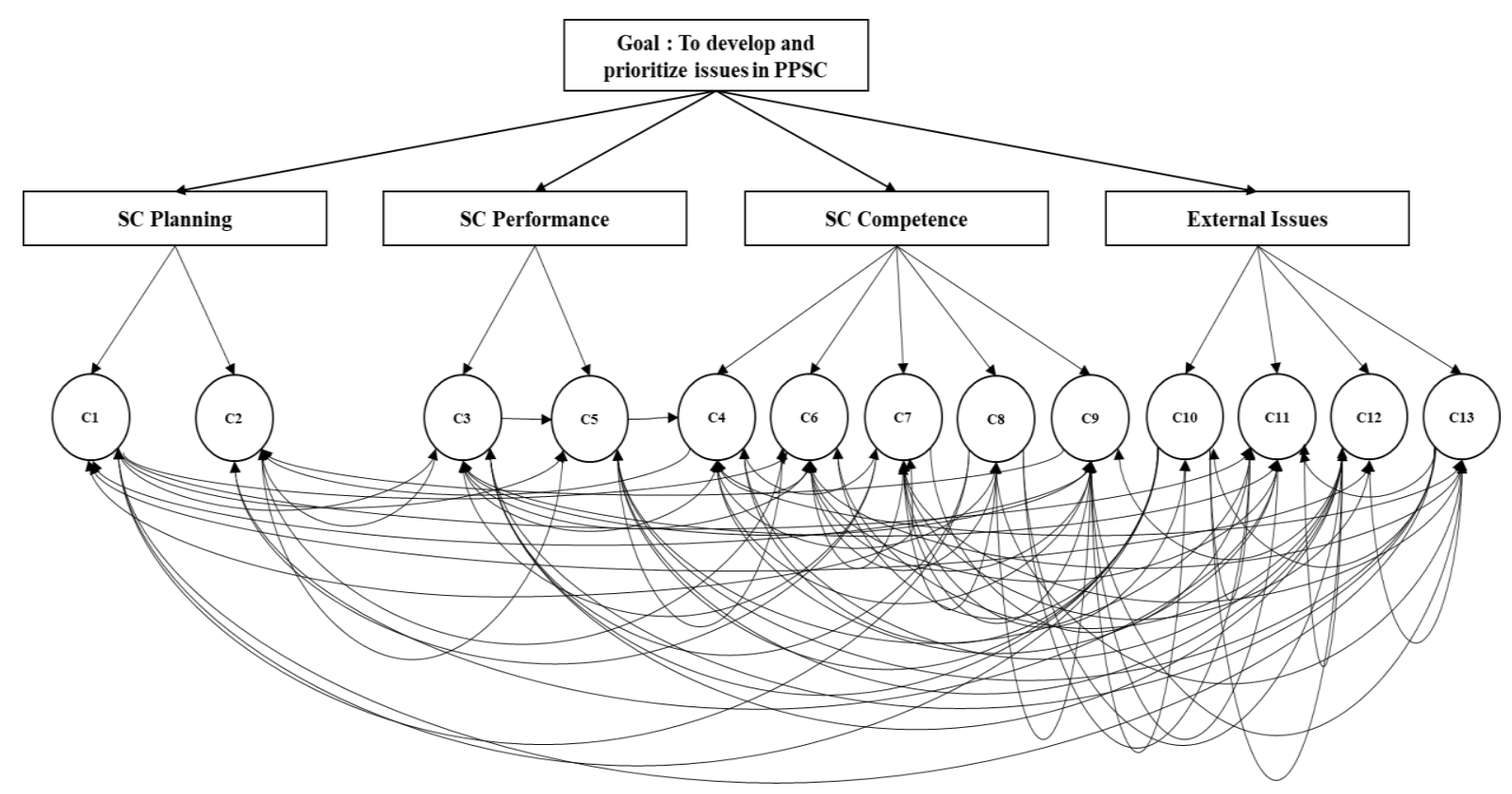

Fig. 5. ANP model to prioritize challenges in PFSCs

The challenges previously identified are classified in four clusters. The priorities among the clusters are generated by pairwise comparison of the clusters. The priority matrix for the clusters is as shown in Table 7.

\section{Table 7}

Cluster matrix for ANP model of PFSC

\begin{tabular}{|c|c|c|c|c|c|}
\hline & Goal & $\begin{array}{c}\text { SC Planning } \\
\text { (CL1) }\end{array}$ & $\begin{array}{c}\text { SC } \\
\text { Performance } \\
\text { (CL2) }\end{array}$ & $\begin{array}{c}\text { SC } \\
\text { Competence } \\
\text { (CL3) }\end{array}$ & $\begin{array}{c}\text { External } \\
\text { Issues (CL4) }\end{array}$ \\
\hline $\begin{array}{c}\text { Goal } \\
\text { SC Planning } \\
\text { (CL1) }\end{array}$ & 0.000 & 0.000 & 0.000 & 0.000 & 0.000 \\
\hline $\begin{array}{c}\text { SC Performance } \\
\text { (CL2) }\end{array}$ & 0.237 & 0.099 & 0.213 & 0.134 & 0.383 \\
\hline $\begin{array}{c}\text { SC Competence } \\
\text { (CL3) }\end{array}$ & 0.531 & 0.537 & 0.425 & 0.424 & 0.135 \\
\hline $\begin{array}{c}\text { External Issues } \\
\text { (CL4) }\end{array}$ & 0.091 & 0.436 & 0.086 & 0.097 & 0.175 \\
\hline
\end{tabular}

The unweighted super-matrix generated from the local priority weight inputs is as shown in Table 8.

\section{Table 8}

Unweighted super-matrix for ANP model of PFSC

\begin{tabular}{|c|c|c|c|c|c|c|c|c|c|c|c|c|c|c|c|c|c|}
\hline & CL1 & CL2 & CL3 & CL4 & $\mathrm{C} 1$ & C2 & C3 & C4 & c5 & C6 & C7 & C8 & C9 & $\mathrm{C} 10$ & C11 & C12 & $\mathrm{C} 13$ \\
\hline CL1 & 0 & 0 & 0 & 0 & 0 & 0 & 0 & 0 & 0 & 0 & 0 & 0 & 0 & 0 & 0 & 0 & 0 \\
\hline CL2 & 0 & 0 & 0 & 0 & 0 & 0 & 0 & 0 & 0 & 0 & 0 & 0 & 0 & 0 & 0 & 0 & 0 \\
\hline
\end{tabular}




\begin{tabular}{|l|r|r|r|r|r|r|r|r|r|r|r|r|r|r|r|r|r|r|}
\hline CL3 & 0 & 0 & 0 & 0 & 0 & 0 & 0 & 0 & 0 & 0 & 0 & 0 & 0 & 0 & 0 & 0 & 0 \\
\hline CL4 & 0 & 0 & 0 & 0 & 0 & 0 & 0 & 0 & 0 & 0 & 0 & 0 & 0 & 0 & 0 & 0 & 0 \\
\hline C1 & 0.250 & 0 & 0 & 0 & 0 & 0 & 0 & 0 & 0 & 0 & 0.667 & 1.000 & 0.250 & 1.000 & 0 & 1.000 & 1.000 \\
\hline C2 & 0.750 & 0 & 0 & 0 & 0 & 0 & 1.000 & 1.000 & 0 & 0 & 0.333 & 0 & 0.750 & 0 & 1.000 & 0 & 0 \\
\hline C3 & 0 & 0.200 & 0 & 0 & 1.000 & 0 & 0 & 0 & 0 & 0 & 1.000 & 0 & 1.000 & 0.200 & 1.000 & 0.143 & 0.200 \\
\hline C4 & 0 & 0 & 0.270 & 0 & 0.456 & 0 & 0.614 & 0 & 0.800 & 0.217 & 0 & 0.285 & 0.431 & 0.461 & 0.637 & 0.274 & 0.157 \\
\hline C5 & 0 & 0.800 & 0 & 0 & 0 & 0 & 1.000 & 0 & 0 & 0 & 0 & 0 & 0 & 0.800 & 0 & 0.857 & 0.800 \\
\hline C6 & 0 & 0 & 0.048 & 0 & 0.129 & 1.000 & 0.117 & 0.084 & 0.200 & 0 & 0.297 & 0.052 & 0.267 & 0.236 & 0.105 & 0.150 & 0.094 \\
\hline C7 & 0 & 0 & 0.420 & 0 & 0.348 & 0 & 0 & 0.293 & 0 & 0.412 & 0 & 0.495 & 0.181 & 0.168 & 0 & 0.472 & 0.442 \\
\hline C8 & 0 & 0 & 0.184 & 0 & 0 & 0 & 0 & 0.476 & 0 & 0.066 & 0.618 & 0 & 0.121 & 0 & 0 & 0 & 0.226 \\
\hline C9 & 0 & 0 & 0.078 & 0 & 0.066 & 0 & 0.268 & 0.147 & 0 & 0.305 & 0.089 & 0.168 & 0 & 0.135 & 0.258 & 0.104 & 0.081 \\
\hline C10 & 0 & 0 & 0 & 0.280 & 0 & 0 & 0 & 0 & 0 & 0 & 0.067 & 0 & 0.106 & 0 & 0 & 0 & 0.635 \\
\hline C11 & 0 & 0 & 0 & 0.079 & 0.750 & 1.000 & 1.000 & 0.333 & 1.000 & 0.200 & 0.148 & 0.250 & 0.701 & 0.333 & 0 & 0.167 & 0.078 \\
\hline C12 & 0 & 0 & 0 & 0.501 & 0.250 & 0 & 0 & 0 & 0 & 0 & 0.294 & 0.095 & 0 & 0.667 & 0 & 0 & 0.287 \\
\hline C13 & 0 & 0 & 0 & 0.140 & 0 & 0 & 0 & 0.667 & 0 & 0.800 & 0.491 & 0.065 & 0.193 & 0 & 0 & 0.833 & 0 \\
\hline
\end{tabular}

The weighted super-matrix obtained by multiplying relevant components with cluster priority weight is shown in Table 9.

Table 9.

Weighted super-matrix for ANP model of PFSC

\begin{tabular}{|c|c|c|c|c|c|c|c|c|c|c|c|c|c|c|c|c|c|}
\hline & CL1 & CL2 & CL3 & CL4 & $\mathrm{C} 1$ & C2 & C3 & C4 & c5 & C6 & C7 & C8 & C9 & C10 & C11 & $\mathrm{C} 12$ & $\mathrm{C} 13$ \\
\hline CL1 & 0 & 0 & 0 & 0 & 0 & 0 & 0 & 0 & 0 & 0 & 0 & 0 & 0 & 0 & 0 & 0 & 0 \\
\hline CL2 & 0 & 0 & 0 & 0 & 0 & 0 & 0 & 0 & 0 & 0 & 0 & 0 & 0 & 0 & 0 & 0 & 0 \\
\hline CL3 & 0 & 0 & 0 & 0 & 0 & 0 & 0 & 0 & 0 & 0 & 0 & 0 & 0 & 0 & 0 & 0 & 0 \\
\hline CL4 & 0 & 0 & 0 & 0 & 0 & 0 & 0 & 0 & 0 & 0 & 0 & 0 & 0 & 0 & 0 & 0 & 0 \\
\hline $\mathrm{Cl}$ & 0.250 & 0 & 0 & 0 & 0 & 0 & 0 & 0 & 0 & 0 & 0.089 & 0.232 & 0.033 & 0.383 & 0 & 0.383 & 0.383 \\
\hline C2 & 0.750 & 0 & 0 & 0 & 0 & 0 & 0.213 & 0.232 & 0 & 0 & 0.045 & 0 & 0.100 & 0 & 0.553 & 0 & 0 \\
\hline C3 & 0 & 0.200 & 0 & 0 & 0.099 & 0 & 0 & 0 & 0 & 0 & 0.424 & 0 & 0.424 & 0.027 & 0.194 & 0.019 & 0.027 \\
\hline C4 & 0 & 0 & 0.270 & 0 & 0.245 & 0 & 0.261 & 0 & 0.665 & 0.169 & 0 & 0.171 & 0.149 & 0.081 & 0.161 & 0.048 & 0.027 \\
\hline C5 & 0 & 0.800 & 0 & 0 & 0 & 0 & 0.276 & 0 & 0 & 0 & 0 & 0 & 0 & 0.108 & 0 & 0.115 & 0.108 \\
\hline C6 & 0 & 0 & 0.048 & 0 & 0.069 & 0.596 & 0.050 & 0.050 & 0.166 & 0 & 0.103 & 0.031 & 0.092 & 0.041 & 0.026 & 0.026 & 0.016 \\
\hline C7 & 0 & 0 & 0.420 & 0 & 0.187 & 0 & 0 & 0.176 & 0 & 0.322 & 0 & 0.297 & 0.063 & 0.029 & 0 & 0.083 & 0.077 \\
\hline C8 & 0 & 0 & 0.184 & 0 & 0 & 0 & 0 & 0.285 & 0 & 0.051 & 0.213 & 0 & 0.042 & 0 & 0 & 0 & 0.040 \\
\hline C9 & 0 & 0 & 0.078 & 0 & 0.036 & 0 & 0.114 & 0.088 & 0 & 0.238 & 0.030 & 0.101 & 0 & 0.024 & 0.065 & 0.018 & 0.014 \\
\hline $\mathrm{C} 10$ & 0 & 0 & 0 & 0.280 & 0 & 0 & 0 & 0 & 0 & 0 & 0.006 & 0 & 0.010 & 0 & 0 & 0 & 0.195 \\
\hline C11 & 0 & 0 & 0 & 0.079 & 0.273 & 0.404 & 0.086 & 0.056 & 0.169 & 0.044 & 0.014 & 0.042 & 0.068 & 0.102 & 0 & 0.051 & 0.024 \\
\hline $\mathrm{C} 12$ & 0 & 0 & 0 & 0.501 & 0.091 & 0 & 0 & 0 & 0 & 0 & 0.029 & 0.016 & 0 & 0.205 & 0 & 0 & 0.088 \\
\hline $\mathrm{C} 13$ & 0 & 0 & 0 & 0.140 & 0 & 0 & 0 & 0.112 & 0 & 0.176 & 0.048 & 0.110 & 0.019 & 0 & 0 & 0.256 & 0 \\
\hline
\end{tabular}

The weighted super-matrix, from Table 9 is raised to limiting powers to generate the global priorities of the challenges. To understand the combined significance of results from both ISM as well ANP, the priority weight from ANP are multiplied with ISM hierarchy levels. The rankings of the identified challenges in PFSCs for sustainability are given in Table 10.

Table 10. Final priorities of the challenges to sustainability in PFSC

\begin{tabular}{|c|c|c|c|c|c|}
\hline Rank & $\mathrm{C}_{\text {index }}$ & $\begin{array}{c}\text { Global Priority } \\
\text { Weight }\end{array}$ & Issues/Challenge to PFSC & ISM hierarch level & Level * weights \\
\hline 1 & $\mathrm{C} 4$ & 0.129 & Lack of Quality Control & 2 & .258 \\
\hline 2 & $\mathrm{C} 2$ & 0.122 & Poor Demand Management & 1 & .122 \\
\hline
\end{tabular}




\begin{tabular}{|c|c|c|c|c|c|}
\hline 3 & C6 & 0.118 & $\begin{array}{c}\text { Lack of Traceability and Supply Chain } \\
\text { Visibility }\end{array}$ & 2 & .236 \\
\hline 4 & C11 & 0.106 & Uncertain Market Prices & 1 & .106 \\
\hline 5 & C7 & 0.103 & Lack of Horizontal Integration of Farmers & 3 & .309 \\
\hline 6 & C3 & 0.102 & Poor Logistics Performance & 2 & .204 \\
\hline 7 & C9 & 0.072 & Poor Use Of ICT & 2 & .144 \\
\hline 8 & C8 & 0.070 & Poor Pre-Harvest Management & 4 & .280 \\
\hline 9 & C1 & 0.059 & Lack of Perishability Related SC Design & 3 & .177 \\
\hline 10 & C13 & 0.053 & Lack of Government Regulation And & 5 & .265 \\
\hline 11 & C5 & 0.037 & Support & 3 & .111 \\
\hline 12 & C12 & 0.017 & Poor Cold Chain Infrastructure & 3 & .051 \\
\hline 13 & C10 & 0.0012 & Infrastructure Issues & 5 & .060 \\
\hline
\end{tabular}

The final priority generated includes hierarchical and contextual significance of factors from ISM, and pairwise comparison based global priority weights from ANP. It thus utilizes the strengths of both ISM and ANP to generate the final priority weights of the challenges to sustainability in PFSCs.

\section{Discussion}

Decision making is an inherently bounded rational problem. Prescriptive decision analysis, thus, provides the theoretical grounds to support the efficacy and effectiveness of decision making. This research presents a decision support problem of identifying preferences among the challenges to sustainability in PFSCs. Based on prescriptive decision theory, ISM-ANP methodology is selected to investigate and generate a priority among the challenges to sustainability in PFSCs.

Based on the results of integrated ISM-ANP methodology, as shown in Table 10, lack of horizontal integration of farmers (C7), is the highest priority challenge with a combined score of 0.309. Poor pre-harvest management (C8), 0.280; lack of government regulation and support (C13), 0.265; are the next two top priority challenges; followed by lack of quality control (C4), 0.258 ; lack of traceability and supply chain visibility (C6), 0.236 ; and logistics performance (C3), 0.204. The average of the combined score is 0.179 , thus, challenges with scores greater than 0.179, are assumed to have greater importance for sustainability in PFSCs. The final priority order of the challenges to sustainability in PFSCs, based on the integrated ISM-ANP approach is, C7-C8-C13-C4-C6-C3-C1-C9-C2-C5-C11-C10-C12.

To understand the interrelationships between the identified challenges to sustainability in PFSCs, ISM methodology was used. The results of which, as illustrated in Fig. 3, propose five levels of a hierarchical structure of the challenges to sustainability in PFSCs. Lack of 
government support and regulations (C13) and infrastructure issues $(\mathrm{C} 10)$ are at the highest level, 5. Policy support and efforts from government is a major enabler for sustainability in PFSCs (Kirwan et al., 2017; Sharma et al., 2019). Government mediation essentially enables industry-wide adoption quality and safety standards, and environmental management systems, through legislation and regulatory control, policy for voluntary sustainable practice uptake, and civil society intervention (Gunningham, 2007). Government support is also necessary for horizontal integration of farmers through farm producer organization (FPOs) and cooperatives (Ali et al., 2018; Mangla et al., 2018). Various government initiatives are critical for educating and training farmers for pre-harvest management, to minimize farm losses (Govindan, 2018b), and follow sustainable farming practices. In developing nations like India, poor infrastructure is often cited as a major reason for high farm end losses of perishables (Chauhan et al., 2019; Gokarn and Kuthambalayan, 2017; Negi and Anand, 2016), thus infrastructure issues are specifically relevant in PFSCs in India. Poor pre-harvest management (C8) is at level 4. Preharvest management significantly affects the production quality of perishables (Gokarn and Kuthambalayan, 2017; Hodges et al., 2011). These results are also validated from MICMAC analysis, Fig. 4, where infrastructure issues (C10) and poor pre-harvest management (C8) are classified in the independent region. The mitigation of challenges to sustainability at level 4 and level 5 have the highest potential of mitigating other challenges to sustainability at lower levels.

Lack of perishability related SC design (C1), poor temperature control (C5), poor cold chain infrastructure (C12), and lack of horizontal integration of farmers (C7) occupy level 3. In India, the agriculture sector is highly disaggregating; farmers with small farm holdings do not have a sufficient scale of production and economic capability to invest in technologies at the production and distribution level (Gokarn and Kuthambalayan, 2017), which establishes the significance of $\mathrm{C} 7$. As a result, lack of investment in advanced technologies and poor economic viability of cold chain, $\mathrm{C} 1, \mathrm{C} 5$, and $\mathrm{C} 12$ are of significance for the sustainability of PFSCs. The challenges up to level three have high driving power and thus have high input significance in the PFSCs, as these challenges impact other challenges significantly. Lack of quality control (C4), lack of traceability, and supply chain visibility (C2), poor logistics performance (C3), and poor use of ICT (C9) are at level 2. Uncertain market prices (11) and poor demand management (C2) occupy the top levels in the model. These challenges may be seen as outputs for the system as they are related to all other challenges. The same has been validated from MICMAC analysis, as the dependent region consists of three challenges, uncertain market 
prices $(\mathrm{C} 11)$, poor demand management $(\mathrm{C} 2)$ and poor logistics performance $(\mathrm{C} 3)$. These challenges are deemed important concerning the sustainable performance of PFSCs.

Seven out of thirteen challenges are found to be in the linkage region. Poor use of ICT (C9), lack of quality control (C4), lack of traceability (C6), lack of perishability related SC design (C1), lack of horizontal integration of farmer (C7), lack of government regulation and support (C13), lack of cold chain infrastructure (C12) are all in this region. Challenges in the linkage region have a strong driving along with strong dependence relation with other challenges. Challenges in this region affect themselves as much as they affect others. Only one challenge, poor temperature control (C5), lies in the autonomous region. Challenges in this region are disconnected from the system as they have low dependence and low driving power. From ISMMICMAC analysis, it may be identified that, infrastructure issues $(\mathrm{C} 10)$, poor pre-harvest management $(\mathrm{C} 8)$, poor cold chain infrastructure $(\mathrm{C} 12)$, lack of government regulation and support (C13), are found to have strong influence as well as strong root cause significance over other sustainability related challenges in PFSCs. Further, poor demand management (C2), poor logistics performance (C3), and uncertain market prices (C11), may be identified as significant challenges for the performance of sustainability in PFSCs.

To further assess their importance, to rank and prioritize these issues, the ANP model was formed, as shown in Fig. 5. The ranking obtained from the ANP model with ISM inputs is: $\mathrm{C} 4>\mathrm{C} 2>\mathrm{C} 6>\mathrm{C} 11>\mathrm{C} 7>\mathrm{C} 3>\mathrm{C} 9>\mathrm{C} 8>\mathrm{C} 1>\mathrm{C} 13>\mathrm{C} 5>\mathrm{C} 12>\mathrm{C} 10$. It is evident that lack of quality control (C4), and poor demand management (C2), occupy the top two spots with evidently high priority scores. Lack of traceability and supply chain visibility (C6) and uncertain market prices (C11) occupy the next two spots. The results seem to be slightly in contradiction with the results of the ISM model. However, similar outcomes have been reported by previous studies that have used ISM-ANP modelling (Bhadani et al., 2016; Govindan et al., 2016). They revealed that the ISM predicts those factors which are at higher hierarchy levels have greater influence in the problem. Meanwhile, the ANP predicts those factors with the lowest hierarchy levels, with high dependence, have the highest importance. This explains the contradiction in results of ISM-ANP (Govindan et al., 2016). Challenges with higher dependence are generally ranked higher in ISM-ANP. However, another inference that can be drawn is that if a criterion with low dependence is ranked higher than others in the same level of hierarchy, then it may be of high overall significance for the system. The indirect impact of dependence can be validated through further exploration and study of the ISM digraph, e.g., lack of horizontal integration 
of farmers (C7) and poor pre-harvest management (C8) have an indirect impact on lack of quality control (C4). Thus, when lack of quality control (C4) becomes a major issue causing low sustainability performance of PFSCs, it also represents lack of horizontal integration of farmers (C7) and poor pre-harvest management (C8).

The results of the integrated ISM-ANP methodology to analyse their interrelationships and the criticality of challenges to sustainability in PFSC, are in line with the findings in the previous research articles, which identify lack of integration as well as infrastructure challenges (Gardas et al., 2019), poor government policies and technological support (Sharma et al., 2019), wastage and quality of product (Naik and Suresh, 2018), poor farm level infrastructure as major challenges in PFSCs. Further, an important observation in the results, takes forward the TBL theory of sustainability. $\mathrm{C} 7, \mathrm{C} 8$, and $\mathrm{C} 13$, which are the most critical challenges identified in the study, are related to the social dimension of the TBL theory. Mitigation of these top challenges needs greater focus on the social dimension of TBL and require development of farmers - which belong to the bottom-of-pyramid of the economy. Thus, the present research proposes an important enlargement of the TBL theory in social dimension sustainability. The PFSC can be considered as a special case where reforms related to social dimensions of TBL can significantly improve the ecological and environmental aspects.

\section{Managerial Implications}

In developing countries, infrastructure issues at the farm level are highly dominant. Horizontal integration of farmers and improved pre-harvest management, can improve the production quality of PFPs, further reduce their farm level losses and enable environmentally sustainable PFSCs. Horizontal integration of farmers could help organizations better aggregate the farm produce, and work better economies of scale for economic sustainability of the organizations in PFSCs. Efficient and successful aggregation of products need to be given more support from the government, through supportive policies as well as infrastructure development. The experts also agreed that government support is needed to make cold chain operations economically sustainable. While the lack of cold chain infrastructure has been often cited to cause unsustainability in PFSCs in developing countries. The cold chain needs to be complemented with on-farm sorting, grading, packaging, and ripening chambers (NCCD, 2015). Further advanced technologies such as blockchain technology, internet-of-things, and artificial intelligence has vast scope of application in cold chains. These applications can enhance the visibility, tracing and tracking across the PFSC. Thus, perishability focussed design of supply 
chains should be given due importance. Poor quality control is another important issue, so efforts for improving quality are essential. Farmers need to be trained and educated for improved farming practices in terms of sorting, grading, packaging and handling of perishable food products, they also need to be encouraged for enhanced usage of ICT to facilitate the flow of information. Enhanced usage of ICT will not only help in informing farmers about market demand for its production but will also sensitize them to follow environmentally-friendly processes. A considerable variation in prices is seen in the different markets at the same time, this leads to the tendency of hoarding and stocking to fetch higher prices later, which further leads to wastage across the PFSCs. Perishable products need to be marketed swiftly without bottlenecks; thus, the time-temperature performance of supply chains is also important. However, when considering fresh produce like fruits and vegetables, they are usually marketed in the local markets within 48-72 hours. Further, with widespread absence of sufficient cold chain transportation in India, logistics performance assumes greater significance as compared to temperature performance. However, the experts agreed that as the cold chain support for PFSCs increases, temperature management of perishable products will assume greater significance. The results were discussed with the experts to propose recommendation for managing the challenges to the sustainability of PFSCs (Table 11).

Table 11. Recommendations for managing the challenges

\begin{tabular}{|l|l|}
\hline \multicolumn{1}{|c|}{$\begin{array}{c}\text { Prioritized } \\
\text { Challenges }\end{array}$} & \multicolumn{1}{|c|}{ Recommendations } \\
\hline $\begin{array}{l}\text { Lack of horizontal } \\
\text { integration of farmers } \\
\text { (C7) }\end{array}$ & $\begin{array}{l}\text { Formation of FPOs and environmentally safe cooperatives. Focus } \\
\text { should be on local level aggregation and national as well as } \\
\text { international level marketing. FPOs should target global consumers } \\
\text { with a marketing strategy based on environmentally-friendly } \\
\text { practices, food safety, and sustainable resource management. }\end{array}$ \\
\hline $\begin{array}{l}\text { Poor pre-harvest } \\
\text { management (C8) }\end{array}$ & $\begin{array}{l}\text { Investment in new farming, harvesting technologies and training of } \\
\text { farmers. }\end{array}$ \\
\hline $\begin{array}{l}\text { Lack of government } \\
\text { support }\end{array}$ & $\begin{array}{l}\text { Development of standards and regulations. Incentivising farm and } \\
\text { and cold chain investments. Economic incentives to adopting } \\
\text { environmental management systems. }\end{array}$ \\
\hline $\begin{array}{l}\text { Lack of } \\
\text { control (C4) }\end{array}$ & $\begin{array}{l}\text { Contract farming, farmer training, investment in farm level } \\
\text { infrastructure. Educating the farmers about sustainable practices. } \\
\text { Promotion of accreditation like GLOBALGAP certification. }\end{array}$ \\
\hline
\end{tabular}




\begin{tabular}{|c|c|}
\hline & $\begin{array}{l}\text { Customers also show willingness to pay a premium price for } \\
\text { organic, socially and environmentally sustainable products. }\end{array}$ \\
\hline $\begin{array}{l}\text { Lack of traceability } \\
\text { and supply chain } \\
\text { visibility (C6) }\end{array}$ & $\begin{array}{l}\text { Vertical integration of farm produce and compulsory } \\
\text { implementation of traceability across the SC. Eco labelling of farm } \\
\text { produce to enable environmental footprint tracking of products. }\end{array}$ \\
\hline $\begin{array}{l}\text { Poor logistics } \\
\text { performance }(\mathrm{C} 3)\end{array}$ & $\begin{array}{l}\text { Investment in cold logistics and collaborative green transportation } \\
\text { solutions. }\end{array}$ \\
\hline $\begin{array}{l}\text { Lack of perishability } \\
\text { related SC design } \\
\text { (C1) }\end{array}$ & $\begin{array}{l}\text { Identification of facility gaps and development of pack houses, } \\
\text { ripening chambers, food processing hubs at proper locations in the } \\
\text { supply chains. }\end{array}$ \\
\hline Poor use of ICT (C9) & Farmers training and education schemes. \\
\hline $\begin{array}{l}\text { Poor demand } \\
\text { management }(\mathrm{C} 2)\end{array}$ & $\begin{array}{l}\text { Collaborative demand forecasting, information sharing with } \\
\text { farmers, storage facility for surplus produce, contract farming. }\end{array}$ \\
\hline $\begin{array}{l}\text { Poor temperature } \\
\text { control (C5) }\end{array}$ & $\begin{array}{l}\text { Investment in cold chain. Development of multi-product compatible } \\
\text { facilities. }\end{array}$ \\
\hline $\begin{array}{l}\text { Uncertain market } \\
\text { prices }(\mathrm{C} 11)\end{array}$ & $\begin{array}{l}\text { E-market. Improved marketing connectivity, demand information } \\
\text { sharing. Proper storage for surplus production. }\end{array}$ \\
\hline $\begin{array}{l}\text { Infrastructure issues } \\
\text { (C10) }\end{array}$ & $\begin{array}{l}\text { Investment in rural infrastructure, development local markets, } \\
\text { aggregation centres, processing hubs. }\end{array}$ \\
\hline $\begin{array}{l}\text { Poor cold chain }(\mathrm{C} 12) \\
\text { infrastructure }\end{array}$ & $\begin{array}{l}\text { Integrated cold chain solutions with development of allied } \\
\text { infrastructure like pack-houses, ripening units, reefer vehicles } \\
(\mathrm{NCCD}, 2015) \text {. }\end{array}$ \\
\hline
\end{tabular}

\section{CONCLUSION}

The major contribution of the present work is to develop a holistic understanding of the challenges to sustainability in PFSCs. An attempt is made to understand the contextual interrelationships of the identified challenges and identify the priorities among them. The proposed methodology that follows a novel approach in integrating the results of ISM and ANP is used. The ISM based model (Fig. 3.) shows infrastructure issues (C10), lack of government regulation and support (C13), and poor pre-harvest management $(\mathrm{C} 8)$ as the most significant challenges. The results of ISM were validated using MICMAC analysis. The challenges identified are further analysed by using ANP methodology. The final priorities generated by 
the integrated ISM-ANP approach include: C7-C8-C13-C4-C6-C3-C1-C9-C2-C5-C11-C10C12. A combined result analysis concludes that lack of horizontal integration of farmers (C7), poor pre-harvest management (C8), and lack of government regulation and support (C13) are the most significant challenges in PFSCs.

The present study opens up new dimensions of theoretical advancement, which can be pursued by studying and theoretical validation of these factors using organizational theories. Challenges specific to firm resources that are internal to SC can be studied using a resource-based view approach. The challenges that are external to the SC can be studied using resource dependent theory or institutional theory. However, such investigation would require empirical study, thus this is proposed for future research only. The resultant framework of the present work can be used for managing the challenges for sustainability in PFSCs. While the challenges identified in the present study consider the Indian context, the proposed framework may be extended to other developing countries . The challenges identified were modelled based on the subjective knowledge of the field experts, which could be challenging to judge. Further, for India, being one of the fastest growing countries in the world, challenges which may seem critical today might not be so critical in future. The limitation is specifically true for challenges related to infrastructure issues and government support as government is proactively promoting innovations and investments in the domain of agriculture, infrastructure and FSCs. On the methodological front, the proposed methodology of ISM-ANP may suffer from the contextual biases and localized constraints of the experts. To solve this problem, the methodology may be extended with fuzzy theory. Further, ANP becomes tough to execute when the number of criteria and alternatives increase as the number of pairwise comparisons increase severely. This limits the environmental, social as well as business related constraints that we can consider in the problem. The results and implications of the ISM-ANP methodologies need to be validated from organizational theory point of view and need further empirical investigations. Also, current study may be further validated using structural equation modelling (SEM).

\section{References}

Adebanjo, D., 2009. Understanding demand management challenges in intermediary food trading: A case study. Supply Chain Manag. 14, 224-233. https://doi.org/10.1108/13598540910954566

Agi, M.A.N., Nishant, R., 2017. Understanding influential factors on implementing green 
supply chain management practices: An interpretive structural modelling analysis. J. Environ. Manage. 188, 351-363. https://doi.org/10.1016/j.jenvman.2016.11.081

Aiying, R., Akkerman, R., Martin, G., 2011. An optimization approach for managing fresh food quality throughout the supply chain. Int. J. Prod. Econ. 131, 421-429. https://doi.org/10.1016/j.ijpe.2009.11.026

Ali, I., Nagalingam, S., Gurd, B., 2017. Building resilience in SMEs of perishable product supply chains: enablers, barriers and risks. Prod. Plan. Control 28, 1236-1250. https://doi.org/10.1080/09537287.2017.1362487

Ali, I., Nagalingam, S., Gurd, B., Ali, I., 2018. A resilience model for cold chain logistics of perishable products. Int. J. Logist. Manag. 29. https://doi.org/10.1108/IJLM-06-20170147

Amorim, P., Meyr, H., Almeder, C., Almada-Lobo, B., 2013. Managing perishability in production-distribution planning: A discussion and review. Flex. Serv. Manuf. J. 25, 389-413. https://doi.org/10.1007/s10696-011-9122-3

Aung, M.M., Chang, Y.S., 2014a. Traceability in a food supply chain: Safety and quality perspectives. Food Control 39, 172-184. https://doi.org/10.1016/j.foodcont.2013.11.007

Aung, M.M., Chang, Y.S., 2014b. Temperature management for the quality assurance of a perishable food supply chain. Food Control 40, 198-207. https://doi.org/10.1016/j.foodcont.2013.11.016

Balaji, M., Arshinder, K., 2016. Modeling the causes of food wastage in Indian perishable food supply chain. Resour. Conserv. Recycl. 114, 153-167. https://doi.org/10.1016/j.resconrec.2016.07.016

Bhadani, A.K., Shankar, R., Rao, D.V., 2016. Modeling the barriers of service adoption in rural Indian telecom using integrated ISM-ANP. J. Model. Manag. 11, 2-25. https://doi.org/10.1108/JM2-09-2013-0041

Blackburn, J., Scudder, G., 2009. Supply chain strategies for perishable products: The case of fresh produce. Prod. Oper. Manag. 18, 129-137. https://doi.org/10.1111/j.19375956.2009.01016.x

Bosona, T., Gebresenbet, G., 2013. Food traceability as an integral part of logistics management in food and agricultural supply chain. Food Control 33, 32-48. https://doi.org/10.1016/j.foodcont.2013.02.004

Bourlakis, M., Matopoulos, A., 2010. Trends in food supply chain management, in: Delivering Performance in Food Supply Chains. Woodhead Publishing Limited, pp. 511-527. https://doi.org/10.1533/9781845697778.6.511

Chauhan, A., Debnath, R.M., Singh, S.P., 2018. Modelling the drivers for sustainable Agrifood waste management. Benchmarking An Int. J. 25, 981-993. 
Chauhan, A., Kaur, H., Yadav, S., Jakhar, S.K., 2019. A hybrid model for investigating and selecting a sustainable supply chain for agri-produce in India. Ann. Oper. Res. https://doi.org/10.1007/s10479-019-03190-6

Chen, Y., Wang, S., Yao, J., Li, Y., Yang, S., 2018. Socially responsible supplier selection and sustainable supply chain development: A combined approach of total interpretive structural modeling and fuzzy analytic network process. Bus. Strateg. Environ. 27, 1708-1719. https://doi.org/10.1002/bse.2236

Chkanikova, O., 2016. Sustainable Purchasing in Food Retailing: Interorganizational Relationship Management to Green Product Supply. Bus. Strateg. Environ. 25, 478-494. https://doi.org/10.1002/bse.1877

Davis-Sramek, B., Thomas, R.W., Fugate, B.S., 2018. Integrating Behavioral Decision Theory and Sustainable Supply Chain Management: Prioritizing Economic, Environmental, and Social Dimensions in Carrier Selection. J. Bus. Logist. 39, 87-100. https://doi.org/10.1111/jbl.12181

De Hooge, I.E., van Dulm, E., van Trijp, H.C.M., 2018. Cosmetic specifications in the food waste issue: Supply chain considerations and practices concerning suboptimal food products. J. Clean. Prod. 183, 698-709. https://doi.org/10.1016/j.jclepro.2018.02.132

Deng, X., Yang, X., Zhang, Y., Li, Y., Lu, Z., 2019. Risk propagation mechanisms and risk management strategies for a sustainable perishable products supply chain. Comput. Ind. Eng. 1-13. https://doi.org/10.1016/j.cie.2019.01.014

Derens-Bertheau, E., Osswald, V., Laguerre, O., Alvarez, G., 2015. Cold chain of chilled food in France. Int. J. Refrig. 52, 161-167. https://doi.org/10.1016/j.ijrefrig.2014.06.012

Duperrin, J.-C., Godet, M., 1973. Hierarchization method for the elements of a system. An attempt to forecast a nuclear energy system in its societal context.

Faisal, M.N., Al-Esmael, B., Sharif, K.J., 2017. Supplier selection for a sustainable supply chain. Benchmarking An Int. J. 24, 1956-1976. https://doi.org/10.1108/bij-03-20160042

Faisal, M.N., Talib, F., 2016. Implementing traceability in Indian food-supply chains: An interpretive structural modeling approach. J. Foodserv. Bus. Res. 19, 171-196. https://doi.org/10.1080/15378020.2016.1159894

Farooque, M., Zhang, A., Liu, Y., 2019. Barriers to circular food supply chains in China. Supply Chain Manag. An Int. J. In Press.

Food and Agriculture Organization of the United Nations, 2019. Food Loss and Food Waste [WWW Document]. URL http://www.fao.org/food-loss-and-food-waste/en/ (accessed 6.12.19).

French, S., Maule, J., Papamichail, N., 2009. Decision Behaviour Analysis and Support, Cambridge University Press. 
Gardas, B.B., Raut, R.D., Cheikhrouhou, N., Narkhede, B.E., 2019. A hybrid decision support system for analyzing challenges of the agricultural supply chain. Sustain. Prod. Consum. 18, 19-32. https://doi.org/10.1016/j.spc.2018.11.007

Gardas, B.B., Raut, R.D., Narkhede, B., 2018. Evaluating critical causal factors for postharvest losses (PHL) in the fruit and vegetables supply chain in India using the DEMATEL approach. J. Clean. Prod. 199, 47-61. https://doi.org/10.1016/j.jclepro.2018.07.153

Ghadge, A., Kaklamanou, M., Choudhary, S., Bourlakis, M., 2017. Implementing environmental practices within the Greek dairy supply chain Drivers and barriers for SMEs. Ind. Manag. Data Syst. 117, 1995-2014. https://doi.org/10.1108/IMDS-07-20160270

Gligor, D., Tan, A., Nguyen, T.N.T., 2018. The obstacles to cold chain implementation in developing countries: insights from Vietnam. Int. J. Logist. Manag. 29, 942-958. https://doi.org/10.1108/IJLM-02-2017-0026

Gokarn, S., Kuthambalayan, T.S., 2017. Analysis of challenges inhibiting the reduction of waste in food supply chain. J. Clean. Prod. 168, 595-604. https://doi.org/10.1016/j.jclepro.2017.09.028

Govindan, K., 2018a. Sustainable consumption and production in the food supply chain: A conceptual framework. Int. J. Prod. Econ. 195, 419-431. https://doi.org/10.1016/j.ijpe.2017.03.003

Govindan, K., 2018b. Sustainable consumption and production in the food supply chain : A conceptual framework. Int. J. Prod. Econ. 195, 419-431. https://doi.org/10.1016/j.ijpe.2017.03.003

Govindan, K., Madan Shankar, K., Kannan, D., 2016. Application of fuzzy analytic network process for barrier evaluation in automotive parts remanufacturing towards cleaner production - A study in an Indian scenario. J. Clean. Prod. 114, 199-213. https://doi.org/10.1016/j.jclepro.2015.06.092

Gunningham, N., 2007. Incentives to improve farm management: EMS, supply-chains and civil society. J. Environ. Manage. 82, 302-310. https://doi.org/10.1016/j.jenvman.2005.06.016

Halloran, A., Clement, J., Kornum, N., Bucatariu, C., Magid, J., 2014. Addressing food waste reduction in Denmark. Food Policy 49, 294-301. https://doi.org/10.1016/j.foodpol.2014.09.005

Hodges, R.J., Buzby, J.C., Bennett, B., 2011. Postharvest losses and waste in developed and less developed countries: Opportunities to improve resource use. J. Agric. Sci. 149, 3745. https://doi.org/10.1017/S0021859610000936

Hosseini, L., Tavakkoli-Moghaddam, R., Vahdani, B., Mousavi, S.M., Kia, R., 2013. Using 
the Analytical Network Process to Select the Best Strategy for Reducing Risks in a Supply Chain. J. Eng. (United States) 2013. https://doi.org/10.1155/2013/375628

Jonkman, J., Barbosa-Póvoa, A.P., Bloemhof, J.M., 2019. Integrating harvesting decisions in the design of agro-food supply chains. Eur. J. Oper. Res. 276, 247-258. https://doi.org/10.1016/j.ejor.2018.12.024

Joshi, P., Visvanathan, C., 2019. Sustainable management practices of food waste in Asia: Technological and policy drivers. J. Environ. Manage. 247, 538-550. https://doi.org/10.1016/j.jenvman.2019.06.079

Joshi, R., Banwet, D.K., Shankar, R., 2009. Indian cold chain: Modeling the inhibitors. Br. Food J. 111, 1260-1283. https://doi.org/10.1108/00070700911001077

Keivan Zokaei, A., Simons, D.W., 2006. Value chain analysis in consumer focus improvement: A case study of the UK red meat industry. Int. J. Logist. Manag. 17, 141162. https://doi.org/10.1108/09574090610689934

Kirwan, J., Maye, D., Brunori, G., 2017. Acknowledging complexity in food supply chains when assessing their performance and sustainability. J. Rural Stud. 52, 21-32. https://doi.org/10.1016/j.jrurstud.2017.03.008

Kohli, P., 2012. Challenges to Cold-Chain Development.

Langroodi, R.R.P., Amiri, M., 2016. A system dynamics modeling approach for a multi-level, multi-product, multi-region supply chain under demand uncertainty. Expert Syst. Appl. 51, 231-244. https://doi.org/10.1016/j.eswa.2015.12.043

Lau, H., Nakandala, D., Shum, P.K., 2018. A business process decision model for fresh-food supplier evaluation. Bus. Process Manag. J. 24, 716-744. https://doi.org/10.1108/BPMJ01-2016-0015

Liu, H., Zhang, J., Zhou, C., Ru, Y., 2018. Optimal purchase and inventory retrieval policies for perishable seasonal agricultural products. Omega (United Kingdom) 79, 133-145. https://doi.org/10.1016/j.omega.2017.08.006

Lusiantoro, L., Yates, N., Mena, C., Varga, L., 2018. A refined framework of information sharing in perishable product supply chains, International Journal of Physical Distribution and Logistics Management. https://doi.org/10.1108/IJPDLM-08-2017-0250

Malviya, R.K., Kant, R., Gupta, A.D., 2018. Evaluation and Selection of Sustainable Strategy for Green Supply Chain Management Implementation. Bus. Strateg. Environ. 27, 475502. https://doi.org/10.1002/bse.2016

Mangla, S.K., Kumar, P., Barua, M.K., 2014. Flexible decision approach for analysing performance of sustainable supply chains under risks/uncertainty. Glob. J. Flex. Syst. Manag. 15, 113-130. https://doi.org/10.1007/s40171-014-0059-8

Mangla, S.K., Luthra, S., Rich, N., Kumar, D., Rana, N.P., Dwivedi, Y.K., 2018. Enablers to 
implement sustainable initiatives in agri-food supply chains. Int. J. Prod. Econ. 203, 379-393. https://doi.org/10.1016/j.ijpe.2018.07.012

Murthy, D.S., Gajanana, T.M., Sudha, M., Dakshinamoorthy, V., 2009. Marketing \& PostHarvest Losses in Fruits : Its Implications on Availability \& Economy - A Study on Pomegranate in Karnataka. Indian J. Agric. Econ. 64, 259-275.

Musavi, M., Werner, F., Nasiri, M.M., Rahbari, A., Jolai, F., 2019. The vehicle routing and scheduling problem with cross-docking for perishable products under uncertainty: Two robust bi-objective models. Appl. Math. Model. 70, 605-625. https://doi.org/10.1016/j.apm.2019.01.047

Naik, G., Suresh, D.N., 2018. Challenges of creating sustainable agri-retail supply chains. IIMB Manag. Rev. 30, 270-282. https://doi.org/10.1016/j.iimb.2018.04.001

NCCD, 2015. All India Cold-chain Infrastructure Capacity (Assessment of Status \& Gap).

Negi, S., Anand, N., 2016. Factors Leading to Losses and Wastage in the Supply Chain of Fruits and Vegetables Sector in India. Energy, Infrastruct. Transp. Challenges W. Forw. I, 80-105. https://doi.org/10.13140/RG.2.1.2395.5607

Negi, S., Anand, N., 2015. Issues and Challenges in the Supply Chain of Fruits \&amp; Vegetables Sector in India: A Review. Int. J. Manag. Value Supply Chain. 6, 47-62. https://doi.org/10.5121/ijmvsc.2015.6205

Osvald, A., Stirn, L.Z., 2008. A vehicle routing algorithm for the distribution of fresh vegetables and similar perishable food. J. Food Eng. 85, 285-295. https://doi.org/10.1016/j.jfoodeng.2007.07.008

Pinstrup-Andersen, P., Rahmanian, M., Allahoury, A., Guillou, M., Hendriks, S., Hewitt, J., Iwanaga, M., Kalafatic, C., Kliksberg, B., Maluf, R., Murphy, S., Oniang'o, R., Pimbert, M., Sepúlveda, M., Tang, H., 2014. Food losses and waste in the context of sustainable food systems.

Prakash, S., Soni, G., Rathore, A.P.S., Singh, S., 2017. Risk analysis and mitigation for perishable food supply chain: a case of dairy industry. Benchmarking 24, 2-23. https://doi.org/10.1108/BIJ-07-2015-0070

Rais, M., Sheoran, A., 2015. esearch ArticleOpen Access Scope of Supply Chain Management in Fruits and Vegetables in India Keywords Indian Scenario of Fruits and Vegetables Production. J. Food Process. Technol. 6, 427-434. https://doi.org/10.4172/2157-7110.1000427

Raut, R., 2019. Improvement in the Food Losses in Fruits and Vegetable Supply Chain - A Perspective of Cold Third-Party Logistics Approach. Oper. Res. Perspect. 6, 100117. https://doi.org/10.1016/j.orp.2019.100117

Raut, R., Gardas, B.B., 2018. Sustainable logistics barriers of fruits and vegetables: An interpretive structural modeling approach. Benchmarking 25, 2589-2610. 
https://doi.org/10.1108/BIJ-07-2017-0166

Raut, R.D., Gardas, B.B., Kharat, M., Narkhede, B., 2018. Modeling the drivers of postharvest losses - MCDM approach. Comput. Electron. Agric. 154, 426-433. https://doi.org/10.1016/j.compag.2018.09.035

Raut, R.D., Luthra, S., Narkhede, B.E., Mangla, S.K., Gardas, B.B., Priyadarshinee, P., 2019. Examining the performance oriented indicators for implementing green management practices in the Indian agro sector. J. Clean. Prod. 215, 926-943. https://doi.org/S0959652619301568

Rijpkema, W.A., Rossi, R., van der Vorst, J.G.A.J., 2014. Effective sourcing strategies for perishable product supply chains. Int. J. Phys. Distrib. Logist. Manag. 44, 494-510. https://doi.org/10.1108/IJPDLM-01-2013-0013

Ringsberg, H., 2014. Perspectives on food traceability: A systematic literature review. Supply Chain Manag. An Int. J. 19, 558-576. https://doi.org/10.1108/SCM-01-2014-0026

Routroy, S., Behera, A., 2017. Agriculture supply chain: A systematic review of literature and implications for future research. J. Agribus. Dev. Emerg. Econ. 7, 275-302. https://doi.org/10.1108/JADEE-06-2016-0039

Sajjad, A., Eweje, G., Tappin, D., 2019. Managerial perspectives on drivers for and barriers to sustainable supply chain management implementation: Evidence from New Zealand. Bus. Strateg. Environ. 1-13. https://doi.org/10.1002/bse.2389

Sel, Ç., Soysal, M., Çimen, M., 2018. A green model for the catering industry under demand uncertainty. J. Clean. Prod. 167, 459-472. https://doi.org/10.1016/j.jclepro.2017.08.100

Sgarbossa, F., Russo, I., 2017. A proactive model in sustainable food supply chain: Insight from a case study. Int. J. Prod. Econ. 183, 596-606. https://doi.org/10.1016/j.ijpe.2016.07.022

Shabani, A., Saen, R.F., Torabipour, S.M.R., 2012. A new benchmarking approach in Cold Chain. Appl. Math. Model. 36, 212-224. https://doi.org/10.1016/j.apm.2011.05.051

Sharma, Y.K., Mangla, S.K., Patil, P.P., Liu, S., 2019. When challenges impede the process: For circular economy-driven sustainability practices in food supply chain. Manag. Decis. 57, 995-1017. https://doi.org/10.1108/MD-09-2018-1056

Shirish Sangle, 2010. Empirical Analysis of Determinants of Adoption of Proactive Environmental Strategies in India. Bus. Strateg. Environ. 19, 51-63.

Shukla, M., Jharkharia, S., 2013. Agri-fresh produce supply chain management: A state-ofthe-art literature review. Int. J. Oper. Prod. Manag. 33, 114-158. https://doi.org/10.1108/01443571311295608

Siddh, M.M., Soni, G., Jain, R., Sharma, M.K., 2018. Structural model of perishable food supply chain quality (PFSCQ) to improve sustainable organizational performance. 
Benchmarking 25, 2272-2317. https://doi.org/10.1108/BIJ-01-2017-0003

Simon, H.A., 1960. The new science of management decision., The new science of management decision., The Ford distinguished lectures. Harper \& Brothers, New York, NY, US. https://doi.org/10.1037/13978-000

Singh, R., Shabani, A., 2016. the Identification of Key Success Factors in Sustainable Cold Chain Management : Insights From the. J. Oper. Supply Chain Manag. 9, 1-16. https://doi.org/10.12660/joscmv9n2p01-16

Solér, C., Bergstrom, K., Shanahan, H., 2010. Green Supply Chains and the Missing Link Between Environmental Information and Practice. Bus. Strateg. Environ. 25, 14-25. https://doi.org/10.1002/bse

Song, B.D., Ko, Y.D., 2016. A vehicle routing problem of both refrigerated- and general-type vehicles for perishable food products delivery. J. Food Eng. 169, 61-71. https://doi.org/10.1016/j.jfoodeng.2015.08.027

Song, H., Turson, R., Ganguly, A., Yu, K., 2015. Evaluating the effects of supply chain quality management on food firms' performance: The mediating role of food certification and reputation. Int. J. Oper. Prod. Manag. 37, 1541-1562. https://doi.org/http://dx.doi.org/10.1108/MRR-09-2015-0216

Srivastava, S.K., Chaudhuri, A., Srivastava, R.K., 2015. Propagation of risks and their impact on performance in fresh food retail. Int. J. Logist. Manag. 26, 568-602. https://doi.org/10.1108/IJLM-02-2014-0032

Tang, V., Otto, K., Seering, W., 2018. Decision theories and methodologies, Contributions to Management Science. https://doi.org/10.1007/978-3-319-63026-7_2

Taylor, D.H., Fearne, A., 2009. Demand management in fresh food value chains: A framework for analysis and improvement. Supply Chain Manag. 14, 379-392. https://doi.org/10.1108/13598540910980297

Team Inc42, 2017. AgriTech In India: How Startups Are Changing The Face Of Indian Agriculture [Report] [WWW Document]. URL https://inc42.com/buzz/agricultureagritech-india-startups/ (accessed 6.20.18).

Thakkar, J., Deshmukh, S.G., Gupta, A.D., Shankar, R., 2005. Selection of Third-Party Logistics (3PL): A Hybrid Approach Using Interpretive Structural Modeling (ISM) and Analytic Network Process (ANP). Supply Chain Forum An Int. J. 6, 32-46. https://doi.org/10.1080/16258312.2005.11517137

Tyagi, M., Kumar, P., Kumar, D., 2017. Modelling and analysis of barriers for supply chain performance measurement system. Int. J. Oper. Res. 28, 392-414. https://doi.org/10.1504/IJOR.2017.081912

Tyagi, M., Kumar, P., Kumar, D., 2015. Analysis of interactions among the drivers of green supply chain management. Int. J. Bus. Perform. Supply Chain Model. 7, 92-108. 
https://doi.org/10.1504/IJBPSCM.2015.068137

Van Der Vorst, J.G.A.J., Beulens, A.J.M., 2002. Identifying sources of uncertainty to generate supply chain redesign strategies. Int. J. Phys. Distrib. Logist. Manag. 32, 409430. https://doi.org/10.1108/09600030210437951

Viswanadham, N., 2006. Can India be the food basket for the world? 1-163.

Warfield, J.N., 1974. Toward Interpretation of Complex Structural Models. IEEE Trans. Syst. Man Cybern. 4, 405-417. https://doi.org/10.1109/TSMC.1974.4309336

Xiao, X., He, Q., Li, Z., Antoce, A.O., Zhang, X., 2017. Improving traceability and transparency of table grapes cold chain logistics by integrating WSN and correlation analysis. Food Control 73, 1556-1563. https://doi.org/10.1016/j.foodcont.2016.11.019

Zhang, J., 2017. Evaluating regional low-carbon tourism strategies using the fuzzy Delphianalytic network process approach. J. Clean. Prod. 141, 409-419. https://doi.org/10.1016/j.jclepro.2016.09.122

Zhong, B., Yang, F., Chen, Y.L., 2015. Information empowers vegetable supply chain: A study of information needs and sharing strategies among farmers and vendors. Comput. Electron. Agric. 117, 81-90. https://doi.org/10.1016/j.compag.2015.07.009

\section{APPENDIX A}

The present study has been performed to analyze the challenges to sustainability of perishable food supply chains. Thirteen challenges, categorized among three categories, are finalized from literature and expert views. The finalized challenges from literature along with questions asked from the panel of experts are given below.

Phase 1- Identifying the challenges to sustainability of PFSC

Name-

Position-

Education Qualification-

Experience-

1. How do you define your business, from the aspect of product perishability and supply chain?

2. What are the key sustainability related challenges (internal as well as external) in your business? 
3. Explain in brief how the following challenges are relevant to the environmental, social, and economic sustainability of your supply chain. Feel free to add/remove any particular challenge.

Challenges identified from literature and those added/removed by experts

\begin{tabular}{|c|c|c|}
\hline S. No. & Challenges in PFSC & Relevance to supply chain \\
\hline 1 & $\begin{array}{l}\text { Lack of vertical integration of farmers } \\
\text { (removed on expert suggestion) }\end{array}$ & \\
\hline 2 & $\begin{array}{l}\text { Poor sourcing and logistics contracts } \\
\text { (removed on expert suggestion) }\end{array}$ & \\
\hline 3 & $\begin{array}{l}\text { Poor collaborative inventory control } \\
\text { (removed on expert suggestion) }\end{array}$ & \\
\hline 4 & $\begin{array}{l}\text { Supply chain internal process errors } \\
\text { (removed on expert suggestion) }\end{array}$ & \\
\hline 5 & $\begin{array}{l}\text { High installation and operations cost } \\
\text { (removed on expert suggestion) }\end{array}$ & \\
\hline 6 & $\begin{array}{l}\text { Lack of product characteristics and } \\
\text { perishability consideration in SC planning } \\
\text { (C1) }\end{array}$ & \\
\hline 7 & Poor demand management $(\mathrm{C} 2)$ & \\
\hline 8 & Poor logistic performance (C3) & \\
\hline 9 & Lack of quality control (C4) & \\
\hline 10 & Poor temperature management (C5) & \\
\hline 11 & $\begin{array}{l}\text { Lack of traceability and supply chain } \\
\text { visibility (C6) }\end{array}$ & \\
\hline 12 & $\begin{array}{l}\text { Lack of horizontal integration of farmers } \\
\text { (C7) (added on expert suggestion) }\end{array}$ & \\
\hline 13 & $\begin{array}{l}\text { Poor pre-harvest management }(\mathrm{C} 8) \\
\text { (added on expert suggestion) }\end{array}$ & \\
\hline 14 & $\begin{array}{l}\text { Poor use of ICT (C9) (added on expert } \\
\text { suggestion) }\end{array}$ & \\
\hline 15 & Infrastructure issue $(\mathrm{C} 10)$ & \\
\hline 16 & Uncertain market prices $(\mathrm{C} 11)$ & \\
\hline 17 & Poor cold chain infrastructure (C12) & \\
\hline 18 & $\begin{array}{l}\text { Lack of government support and } \\
\text { regulations (C13) }\end{array}$ & \\
\hline
\end{tabular}

Phase II- Analysis of the identified challenges 
The identified set of challenges is further analyzed using ISM methodology to study their interrelationships. We require your judgements to develop the SSIM.

Input the following in the cell $\mathrm{C}_{\mathrm{ij}}$ based on the interrelationships of row $\mathrm{i}$ and column $\mathrm{j}$. $\mathbf{C}_{\mathbf{2 4}}$, denotes the relation "if" row 2 causes column 4, i.e., Poor Demand Management causes/enhances Lack of Quality Control, or not. Similarly, $\mathbf{C} 4 \mathbf{2}$ denotes "if" row 4 causes column 2, i.e., Lack of Quality Control causes/enhances Poor Demand Management, or not. Please indicate the interrelation between these issues with each other based on the following set of instructions.

$\mathrm{V}$ - Issues (i) causes/enhances issue (j), but not vice-versa.

A- Issues (j) causes/enhances issue (i), but not vice-versa.

$\mathrm{X}$ - Issues (i) and (j) cause/enhance each other.

O- no inter-relation between issue (i) and (j).

SSIM for challenges to sustainability of PFSC

\begin{tabular}{|l|l|l|l|l|l|l|l|l|l|l|l|l|l|}
\hline & $\mathbf{1}$ & $\mathbf{2}$ & $\mathbf{3}$ & $\mathbf{4}$ & $\mathbf{5}$ & $\mathbf{6}$ & $\mathbf{7}$ & $\mathbf{8}$ & $\mathbf{9}$ & $\mathbf{1 0}$ & $\mathbf{1 1}$ & $\mathbf{1 2}$ & $\mathbf{1 3}$ \\
\hline 1. Lack of Perishability Related SC Design & 1 & 1 & 1 & 1 & 0 & 0 & 0 & 0 & 0 & 0 & 0 & 1 & 0 \\
\hline 2. Poor Demand Management & 0 & 1 & 0 & 0 & 0 & 0 & 0 & 0 & 0 & 0 & 1 & 0 & 0 \\
\hline 3. Poor Logistics Performance & 0 & 0 & 1 & 1 & 0 & 0 & 0 & 0 & 0 & 0 & 1 & 0 & 0 \\
\hline 4. Lack of Quality Control & 0 & 1 & 0 & 1 & 0 & 1 & 0 & 0 & 1 & 0 & 1 & 0 & 0 \\
\hline 5. Poor Temperature Control & 0 & 0 & 0 & 1 & 1 & 0 & 0 & 0 & 0 & 0 & 1 & 0 & 0 \\
\hline 6. Lack of Traceability and Supply Chain Visibility & 0 & 1 & 0 & 1 & 0 & 1 & 0 & 0 & 1 & 0 & 1 & 0 & 0 \\
\hline 7. Lack of Horizontal Integration of Farmers & 0 & 1 & 1 & 0 & 0 & 1 & 1 & 0 & 1 & 0 & 1 & 0 & 1 \\
\hline 8. Poor Pre-harvest Management & 1 & 0 & 0 & 1 & 0 & 0 & 1 & 1 & 0 & 0 & 1 & 0 & 0 \\
\hline 9. Poor Use of ICT & 0 & 1 & 1 & 0 & 0 & 1 & 1 & 1 & 1 & 0 & 1 & 0 & 1 \\
\hline 10. Infrastructure Issues & 1 & 0 & 1 & 1 & 1 & 0 & 1 & 1 & 0 & 1 & 1 & 0 & 0 \\
\hline 11. Uncertain Market Prices & 0 & 1 & 0 & 1 & 0 & 0 & 0 & 0 & 0 & 0 & 1 & 0 & 0 \\
\hline 12. Poor Cold Chain Infrastructure & 1 & 1 & 1 & 1 & 1 & 1 & 1 & 1 & 0 & 0 & 1 & 1 & 0 \\
\hline 13. Lack Of Government Regulation And Support & 1 & 0 & 0 & 1 & 0 & 1 & 1 & 1 & 0 & 1 & 0 & 1 & 1 \\
\hline
\end{tabular}

Based on the interrelations developed from the ISM methodology, pairwise comparisons required with respect to each challenge are finalized. The pairwise comparisons sets were converted in the form of questionnaire, for easy understanding of the experts. Pairwise Comparisons with respect to the challenge "Lack of Perishability Related SC Design" are shown in the questionnaire below.

a. Cluster1- "SC Competence". 
i.

\begin{tabular}{|c|c|c|c|c|c|c|c|c|}
\hline \multicolumn{9}{|c|}{$\begin{array}{c}\text { With Respect to "Lack of perishability related SC design", compare the relative importance of the following two } \\
\text { issues }\end{array}$} \\
\hline \multicolumn{9}{|c|}{ Ans1 } \\
\hline Extremely & $\begin{array}{l}\text { Very } \\
\text { Strongly }\end{array}$ & Strongly & Moderately & Equal & Moderately & Strongly & $\begin{array}{l}\text { Very } \\
\text { Strongly }\end{array}$ & Extremely \\
\hline $19 \quad 18$ & $17 \quad 16$ & 14 & 12 & 11 & 2 & 4 & 6 & 8 \\
\hline \multicolumn{4}{|c|}{ Lack of horizontal integration of farmers } & \multicolumn{5}{|c|}{ Poor of use of ICT } \\
\hline
\end{tabular}

ii.

\begin{tabular}{|c|c|c|c|c|c|c|c|c|}
\hline \multicolumn{9}{|c|}{ With respect to "lack of perishability related SC design", compare the relative importance of the following two issu } \\
\hline Extremely & $\begin{array}{l}\text { Very } \\
\text { Strongly }\end{array}$ & Strongly & Moderately & Equal & Moderately & Strongly & $\begin{array}{l}\text { Very } \\
\text { Strongly }\end{array}$ & Extremely \\
\hline \multirow{2}{*}{\multicolumn{4}{|c|}{ Lack of horizontal integration of farmers }} & 11 & 3 & $4 \quad 5$ & $6 \quad 7$ & 8 \\
\hline & & & & \multicolumn{5}{|c|}{ Lack of quality control } \\
\hline
\end{tabular}

iii.

With respect to "lack of perishability related SC design", compare the relative importance of the following two issues Ans1

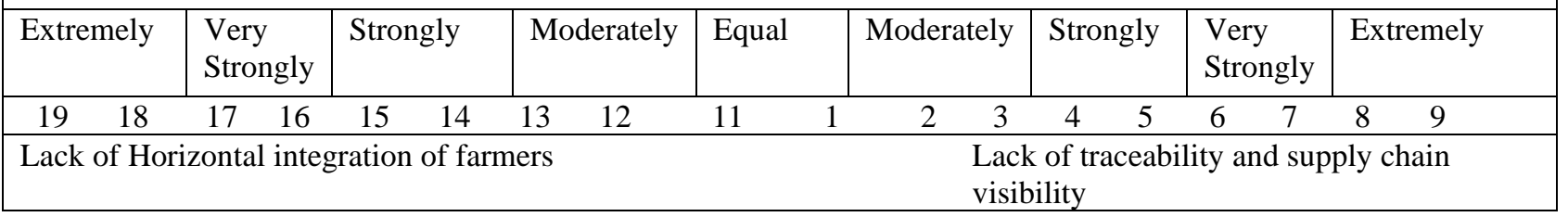

iv.

With respect to "lack of perishability related SC design", compare the relative importance of the following two issues

Ans1

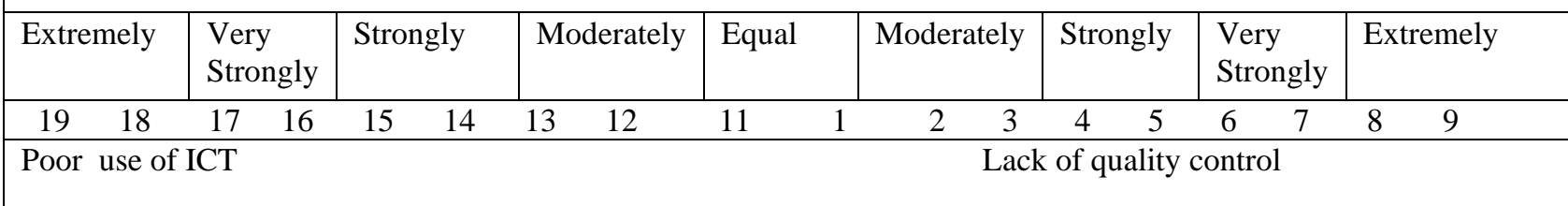

V.

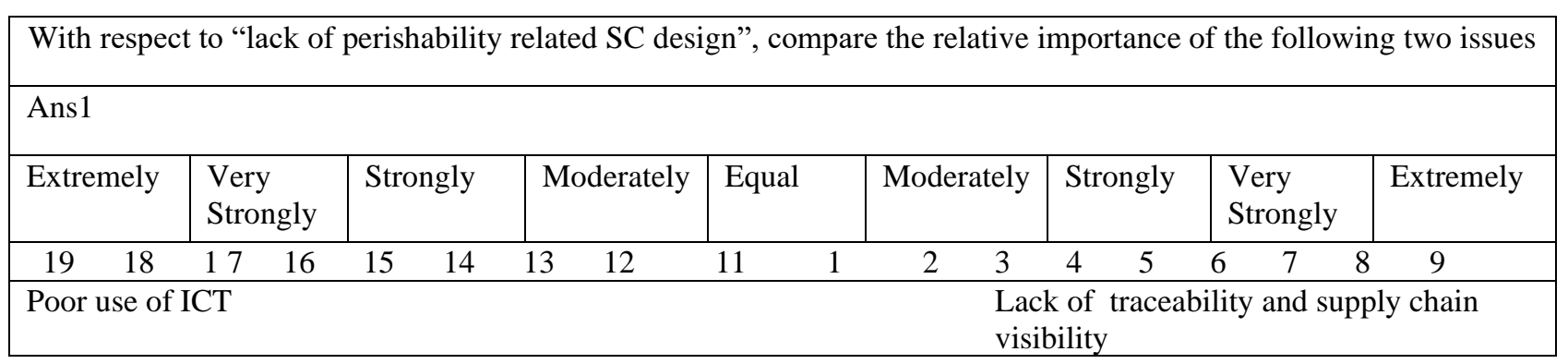


vi.

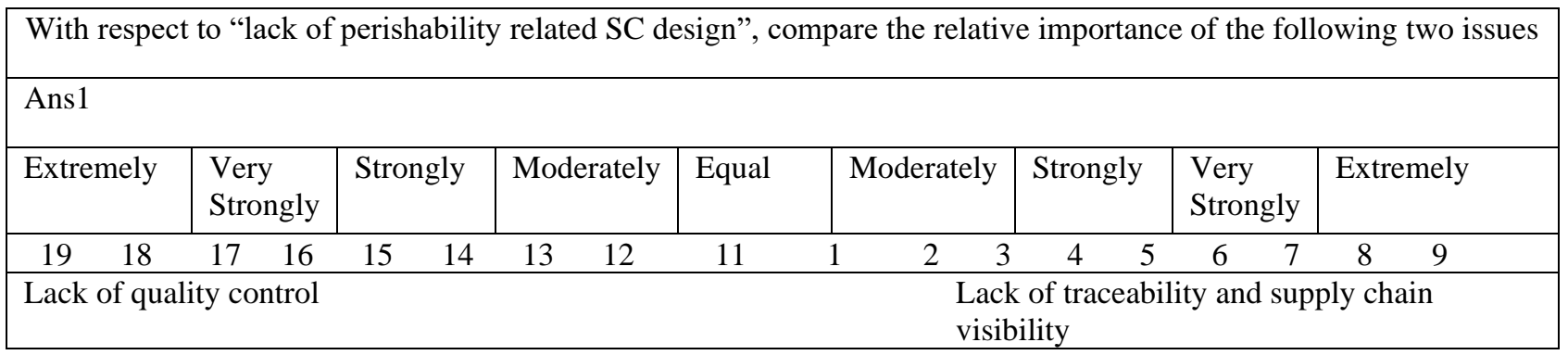

b. Cluster2 "External issues".

i.

With respect to "lack of perishability related SC design", compare the relative importance of the following two issues Ans1

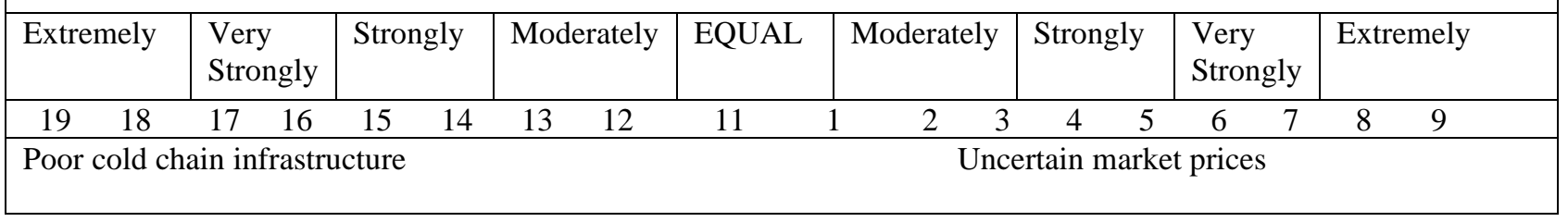

Similarly, pairwise comparisons are conducted for all other challenges. 